University of Rhode Island

DigitalCommons@URI

Open Access Master's Theses

1965

\title{
An Exploratory Study of Repeated Administrations to Preschool Children of the Goodenough-Harris Drawing Test
}

Jyoti Randeri

University of Rhode Island

Follow this and additional works at: https://digitalcommons.uri.edu/theses

\section{Recommended Citation}

Randeri, Jyoti, "An Exploratory Study of Repeated Administrations to Preschool Children of the Goodenough-Harris Drawing Test" (1965). Open Access Master's Theses. Paper 1693.

https://digitalcommons.uri.edu/theses/1693

This Thesis is brought to you for free and open access by DigitalCommons@URI. It has been accepted for inclusion in Open Access Master's Theses by an authorized administrator of DigitalCommons@URI. For more information, please contact digitalcommons-group@uri.edu. 
$B F 723$

Th

22

AN EXPLORATORY STUDY OF REPEATED ADMINISTRATIONS TO PRESCHOOL CHILDREN OF THE COODENOUGH-HARRIS

DRAWING TEST

BY

JYOTI RANDERI

A THESIS SUBMITIED IN PARTIAL FULFILCMENT OF THE REQUTREMENTS FOR THE DEGREE OF

MASTER OF SCIENCE

IN

CHILD DEVELOPMENT AND FAMIY RELATIONS

UNIVERSTTY OF RHODE ISLAND

1965 


\section{ABSTRACT}

The Coodenough Drat-a-Man Text, publlshed in 1926, wos revised by Dale B. Haxris in 1963. The presunt atudy was undertaken to bave bettex undenstanding of pextermange of pratchool chlldren over a pextod of tinte.

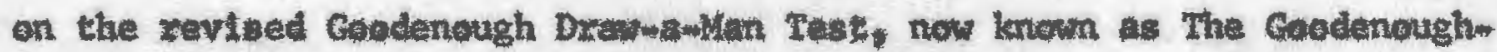
Harris Dratuing Tett. The other purpowes of the study were to find out the relationshlp between Man and Neman Seowes of the Test, and to vertfy the atatentint by Godenough coneerning the indensistency of tast Iteras whose cotacept ane not well integrated in a chlid"s mind.

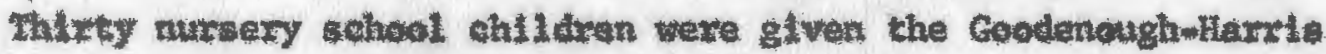
Drawing Test for flve times at every three velus" Intervil. Since the otendard scores given by Harxis are at wetve monthe age intervals, the Iav teores were used in analyaing the watultw.

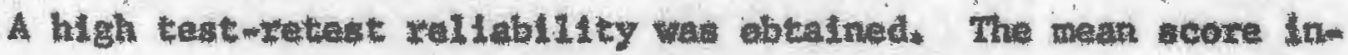

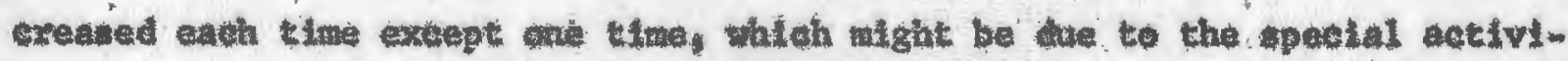
tle which were gatng on in the nuxsery wethol ot that time of teating. The signifteant increase in scores from Testing III onwexds ouggented a pessiblitty of practice effect.

High correletton: obtalned between the Man and Woman seales on all IIve testings Indtcated that the roman seale can be used sucectufully as an "alternate fom" fox the pregehonl chlidren:

The average raw seores of the Drang test correlated substantialiy with $\mathrm{IQ}$ of the Stantend-Binet Intelligexe rent: and bighty with the StanfexdBinet mental age. 
A tendency for Initially le scorers to achleve greater ohenge and Inttlally high scorers to ahleve lessex change, vas observed. Howeve; the statetienlly insignifleant reult call for further resaarch.

The dfffloult test 1 tems shewed ineonsistent eppeavanoe on ffve kestinga, while the eayy test tters appented eandutentiy on Itve testIngs. These reault auggested that the cencept of difficult Itens are not integrated in a child's mitud, which led to the fluctuation in appedrance; whlle on the other hard, the concepts of easy iteas are vell integxated In a child's mindy which resulted in the consistency of appearance. Thus the study arpported the statentent by Goodenough. 


\section{ACKNOWLEDGEMENTS}

The author wishes to extend her sincere appreciation to those who assisted with this thesis. A special thanks goes to her graduate committee: Dr. Russel1 C. Smart. Chasman of the Comittee, for his guldance, assistance, and encouragenent throughout the study, and to Mrs. Mollie S. Swart, and Dr. Frank M. Pelton for thelr helpful suggestions. Gratitude is a1so expressed to Miss Sylvia Lapin. Director of the Nursery School and Miss Rosenary Kohut and Mrs. Barbara Eggert, the Nhrsery School teachers for their cooperation in carrying on the testing in the Nursery School, and to Professor Robext J. Meyer for statistical help. 
TABLE or contintrs

CEAPrist

FAGE

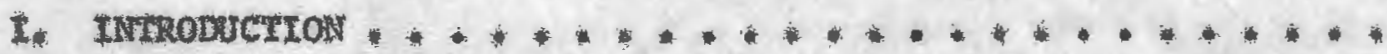

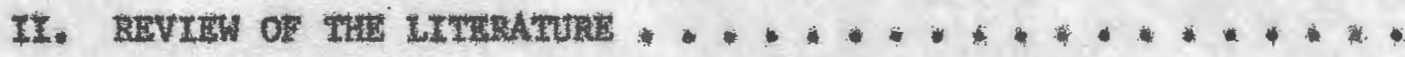

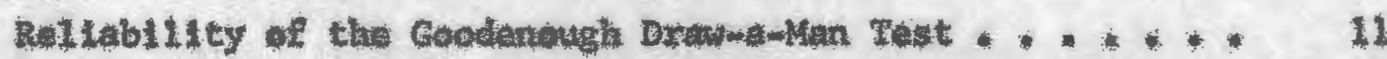

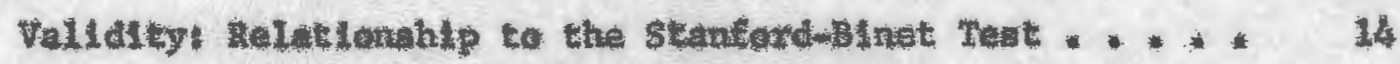

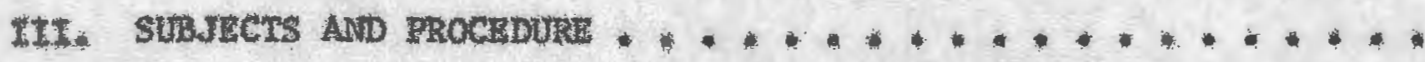

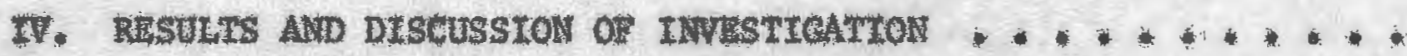

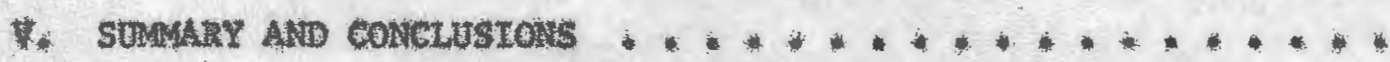
35

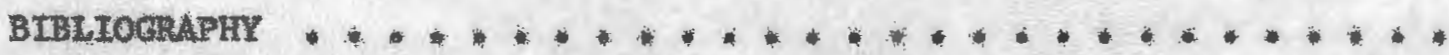


I. Rellabllity of The Coedonough Dreat-a-lian

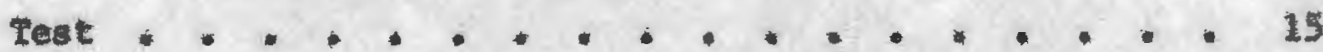

II. Validty Relettonghip to the gtanfoxd-

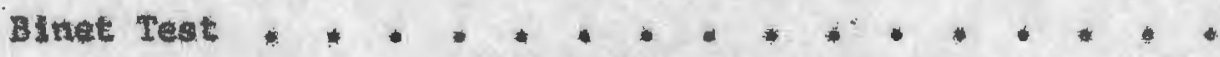

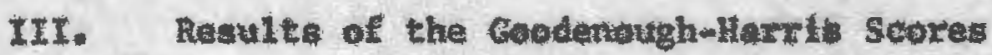

on Five Testlags (Average of Nan and

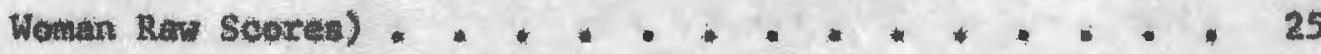

IV. Chunge of Average Ray scares between contatutive

Patre of restinge and betwen the Fitut ent

Last Tostings

V. Correlation between Ian and Woman Raw Seores on

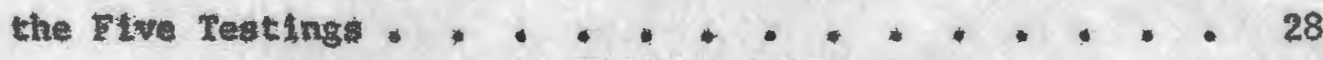

7. Cortelations botneen Rav Scores of Draying Tet

and $I Q$ and Yental Age of Stanford-BInet . . . . .

7I. Felationship betwea the Scores on the Inttial Test

and Amount Change . . . . . . . . . . 30

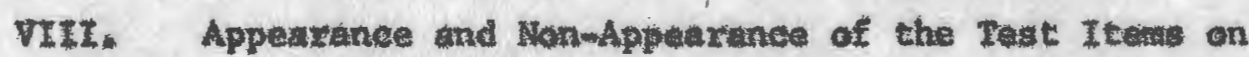

Five Tepting (Fot Man Seale) . . . . . 32

ix. Apposanoe and Non-Appearanes of the Tevt Itemis on

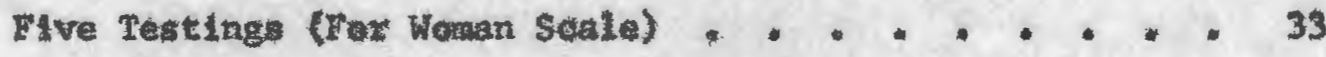

*. Correlation between the Frtquencle of Normppearance

and Appeatance of Test Iteme on Al1 FIve Testiag * . " 34

XI. Sax, Age, Stomford-tuthet IQ and Average Row Scokes

on the Geodendugh-Harria Dxanting Tests.......

xII. Rav seores of the copdenouga-Hantle Drawling Text on 


\section{INTRODUCTION}

The Goodenough Draw-amian Test ocouples a unlque plect in the fleld of mental tents, poscesulng as It does. number of advantage which have

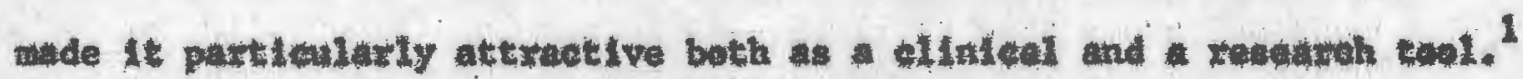
It has been bidely used, to measure the intalkLgence of chllwen, te atudy

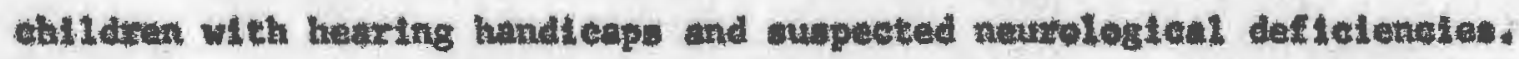

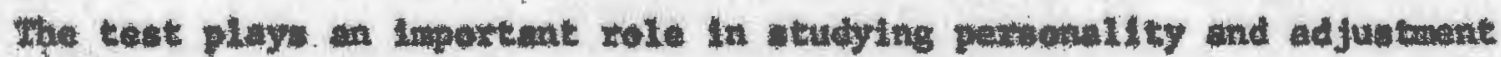
problem and deltnquent beluvior. The test hat bean ubed as projective techalque after moking sone modificatlene. ${ }^{2}$

The 1960 revielen of the stanfoud-Binat, coning twaty-thmee years after the 1937 revtaton, contaln many of the vane Items, sone of which are placed at different year levils than they vare in the curller varalon. It is not elear whethex this te dute to the differenes in intellectual development of children a quartex of century lutas. The fact readins the revision seens destrable. ${ }^{3}$ stewart mentlens that the Drow-am-Man Test measure Intelligente prtmarily, and should be evaluated. It is likely that the mentel age equivalenets attablished wald change turing twentyEtve yeurs. She fuxther suggests that nom vexifleation otudy would

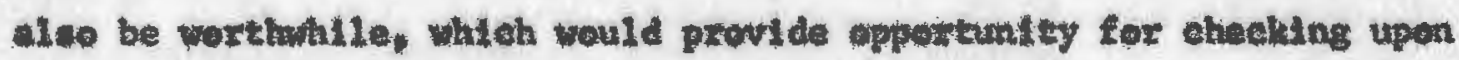

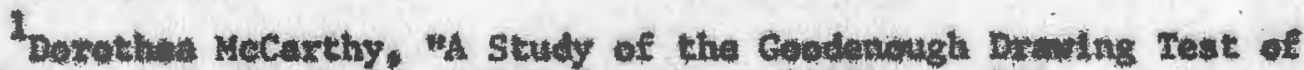
Intelligence," I. Poydiol., XVIII (outobex, 1944), p, 20L.

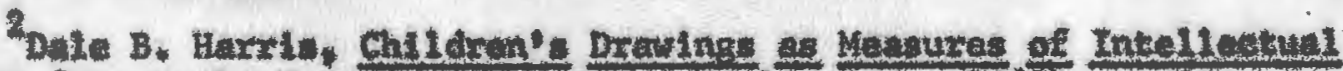

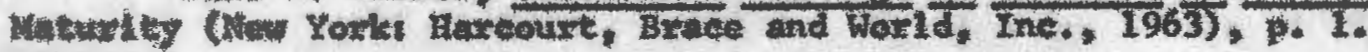

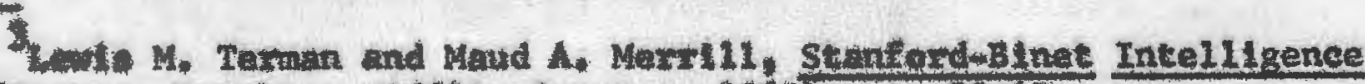

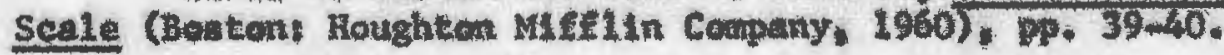


pasalble changes In valldity of any of the fiftcy-ane scoring polnte used In the Condenough Senle 4

Such coneldexations, anong others, led Haxis to undextake the prom ject of restandardicling the teot. 5 Among many goals of revinting the tent, the primury ones waxe to extend the Goodenough seale to include adoleatent years and to develop an "alternate foxu" to the Man scale by deriving an analogous polnt soule for the tigure of wonan. A drawing of the "mele" was Ineluded as a potentital third forte and aleo with the

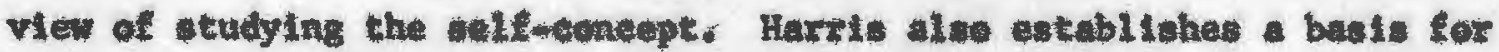
relating the dxaving act to ourint theoretical developatents in the study of perception and concoptual procenoes.6 6

Coodeneugh belleved that for little childxen, draning is a form of cognitive expresston and its purpose la not pribarliy esthetic. The

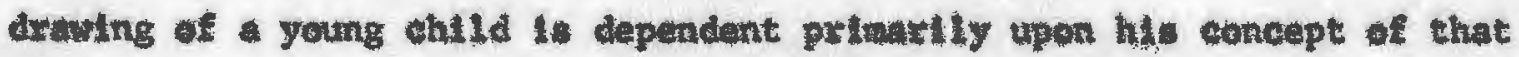

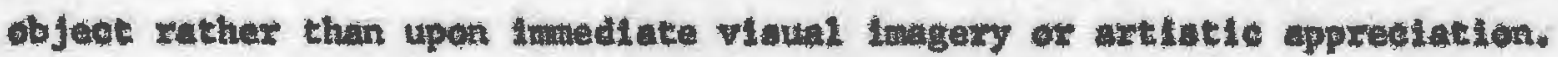
She further explalned the fact that the divelopwental ehanges which talke plaes in children's dxwings do not remain fixed from the time of their firot appearance. Although coodaneugh did not atudy childzen's dxewIngs longleudinally, ahe says that any new characteristie uavally goes

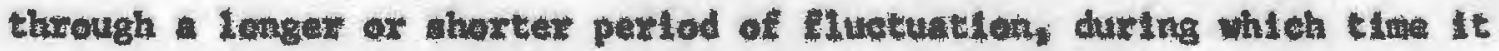

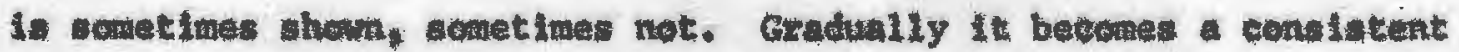

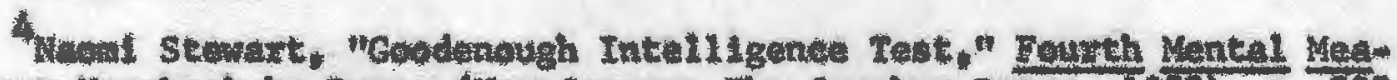
surement Yearbook by Bures (Nen Jersegl the Gryphon Preas; 1953). p. 292.

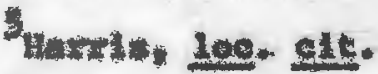

$$
\begin{aligned}
& \text { cold. p.8. }
\end{aligned}
$$


feature of all the drange which the child mukes. ${ }^{7}$ Goodenough aurma*1zes:

It may thus be seld that at any given time a chlld's drawIng will consist of two parte-sthe flrut part mbraeling those characteristies whloh have already becone an integral part of his cencept of the object drmn, and consequently appear invariablys the secend part including the elements which axe in process of betentig Integrated and are therefore show with more or less irregulantty. The frequancy with whtch any given characterfstie tends te appear is a tunetion of the extent to which it has become integrated into the developing concept, and aeasure of the velght wheh should be given to it as an index of eencept development, 8

Hypotheses of the Study. In the IIght of the consideration given above and of the review of IItexature contratned in the next sectlon, the following hypotheses have been fomalated for the study: (1) It Is hypotheslated that the total scores will not vaxy between tests beyond the litits to be expected by chance; (2) as a dxaulng of a woman was develeped as an "alternate form" to the Man Seale, it is hypothentued that a high corralation should be obtalned between the Man and Woman Scores; (3) it is further hypothesized that some test 1terds wil show inconsistency in the appearance on flve teatings, done at regular intervale.

Regsons for the Study. The purpose of this study to to have a better understanding of performance of young ehlidren over a pertod of time on the Goodenoughmitarxis Draning reat. It Is also aimed at finding out the relattondhips between Man and Woman Scores between the Initial scores and the amount of gain at the end of five teatings, and between

${ }^{7}$ Thorance L. Goodehough, Measurement of Intell1genee by Drawings (Now Yoxk: World Book Company, 1926), P. 74.

Ibte. p. 75. 
the Goodenough-Harris Drawing Tett and the Stanterd-Binet. This study is undertaken to verify the statenent by Goodenough regarding the Inconsistency of teat Itens, whose conceptsarenot well integrated in a child": alnd. 
REVLEW OF THE LITLEATURE

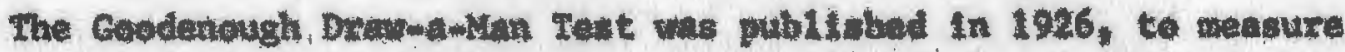

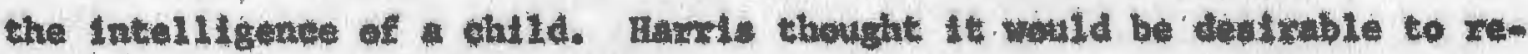
Vive and extend the test. If attempted to extend the seate Into the ado-

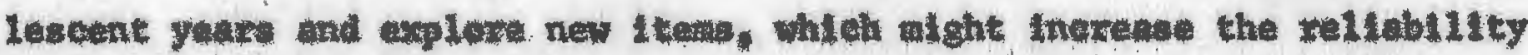
and valldity of the seale, For teoting. new pelnte and the development of

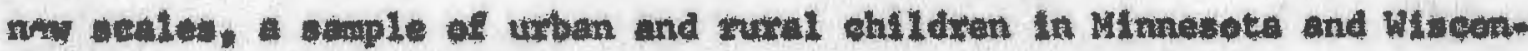
an was selected to reprasent the 1940 cempational distribution accord-

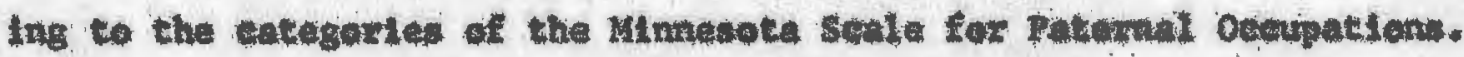

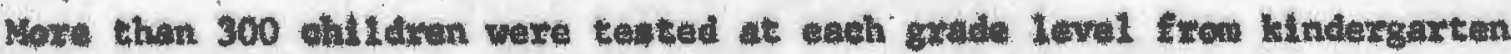
through the ninth grade.

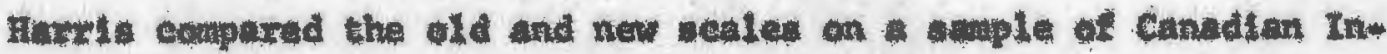

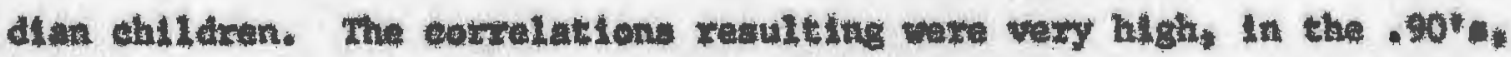
because the ald seale in largely contelned in the new neale,

In order te determine the wathlonshtp between the Man and Hoan Soulan, Hawlis comelated the point scales of two neales for the evennumbered age groups. He obtaind the eorrelation of .76 fex boys and .7 tor glil..$^{3}$ He concluded:

A correlatien of .75 between two rellable fomm of the

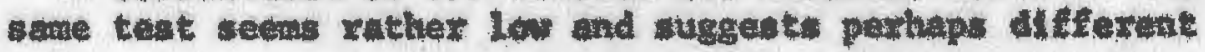

Lale B, Raxte, Children's Dearinge As Measures of Intellectual

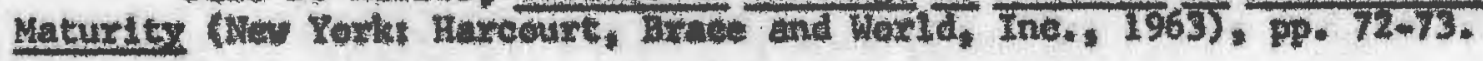

2uble, 9. 99.

Ind +106 . 
obllitleb axe measured by the Man and Woman Seales. How exer, euch scale miny measure several abilities, represented by different kinds of itens, which are in fact only modestiy

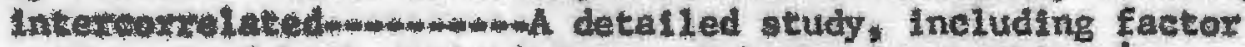

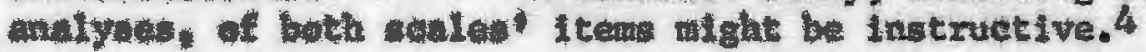

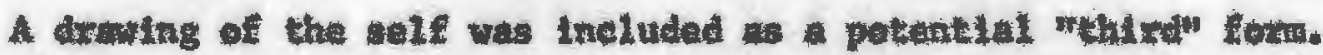

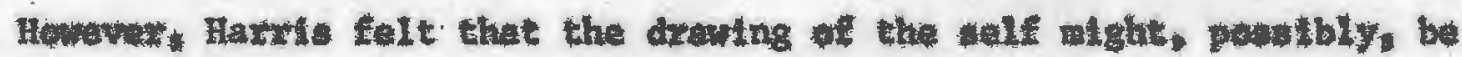

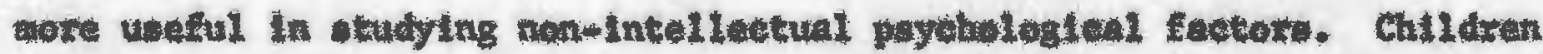

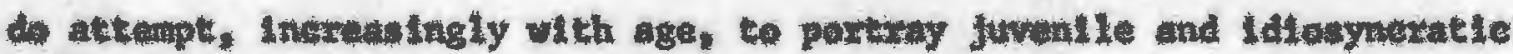

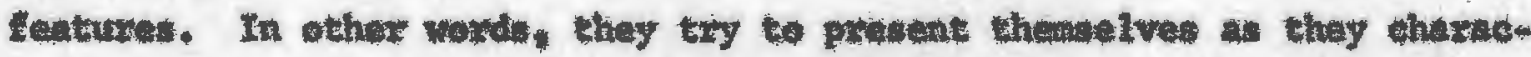

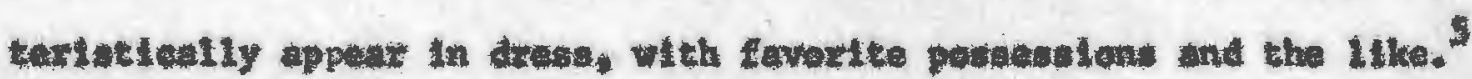

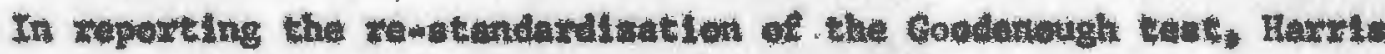
Ghought that it wold be destrable to reglece the notion of intelligince

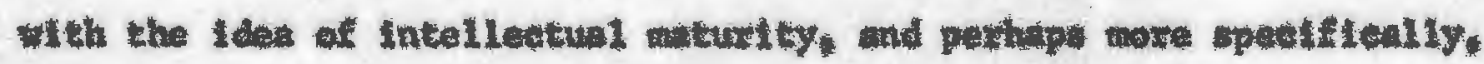

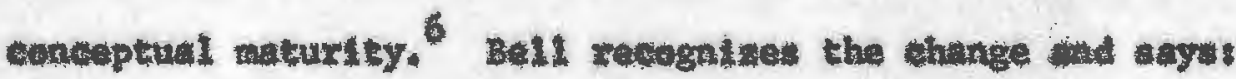

The uth14ty of the sest in measurling mental gxouth fede: att weund age if. Haxile bringe the test into line otth

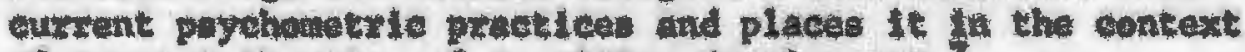
of current theorled of eagnitive development.?

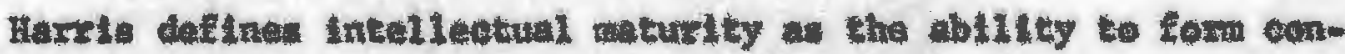

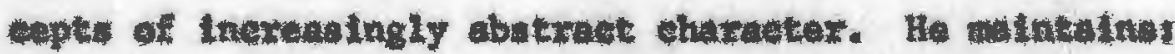

Intellectual activity requited 1) the blitsy to pexcelve, 1. . to discrininate likenese and differenceul 2) the ab111ty to abstract, i.e. to classtfy objects aceording to such Ilkenesaces and differenees; and 3) the ability to generallze; 1.e. to as Lgn an bbject newly experienced to a correct class.

4thet pp. 106-107.

Ite. 226 .

truct. p. 5 .

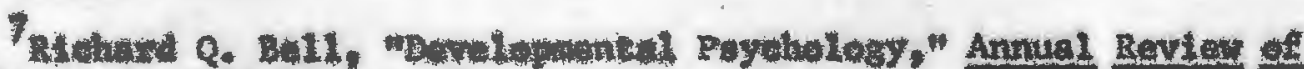
Paychalosy, XVI (1965), p. I6. 
Aceonding to discrininated fentures, propextles ox attributed. These three funetleng taken tagethre. ceoprise the process of concept toxiation, 8

taxis: further states that the procented which include pareeption; conceptualletng and knewing, as well as judglng and reasoning, are called cognteten.

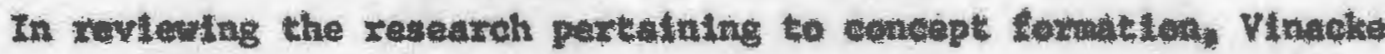

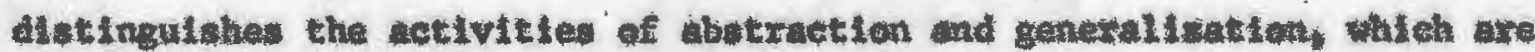
the essentials for eoneept fornation. He says that abstraction atgnitle: Iniking one sencory expexfence to andhex wo that sone detells are left out and other: become dontment. In this sence, a cencept is a reopense

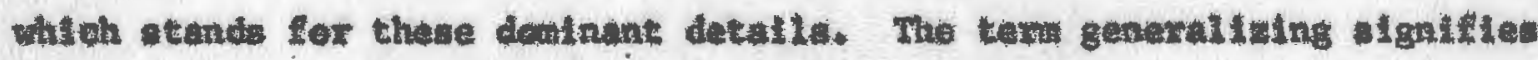
that the deatnant detall or gxoug of dotalis are used as a basie for rooponding sinllaxly to the separate objects IIniked by abstraetfen and for

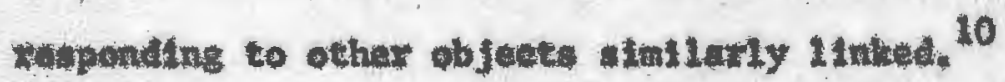

Harris stake that a ehlld's draving of an object is an Index to hil comeaptien of that objeet, that to, of his gach of the essential

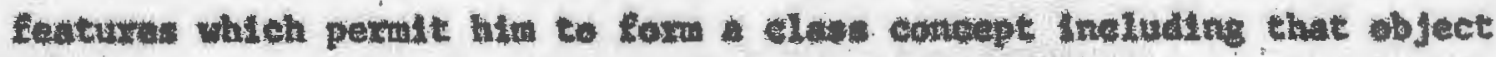

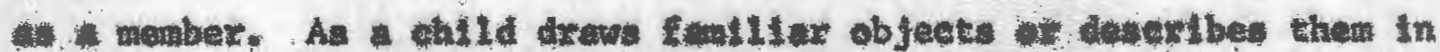

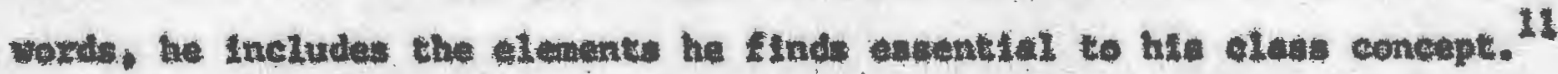

MaFee supports the statement by saytag that;

Axt is a langusge wth whlch a chlld tomaniogtes the expertence. Hit behavior in art is not a aeparate activity

\footnotetext{
and 10. att.

1,ute, p. 6.

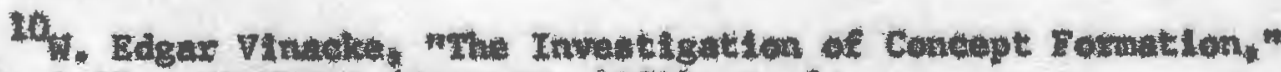

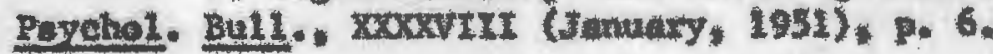

11 Havilt, Log. att.
} 
unrelated to all his other behaviox. He used his in

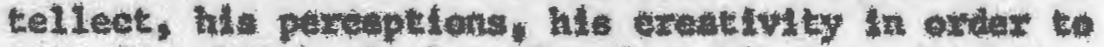

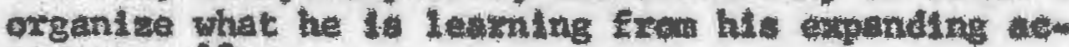
tivites. 12

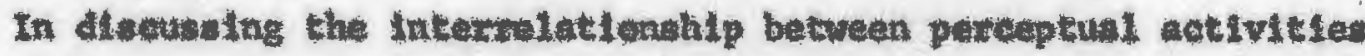
and draving development, Bell matnteins that one of the funetions which the drathe serves is perceptual develogrant. The Invel of the druting is

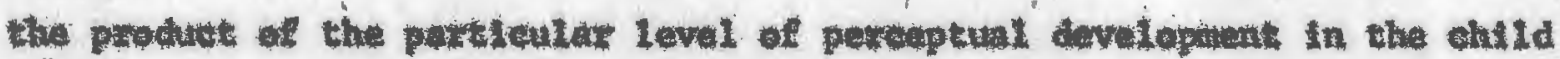
and the exterctee of druving operates as anertant fox hit in the integration of pereaptual procese into Hit total funderioning. 13

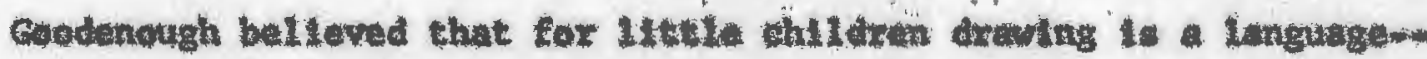

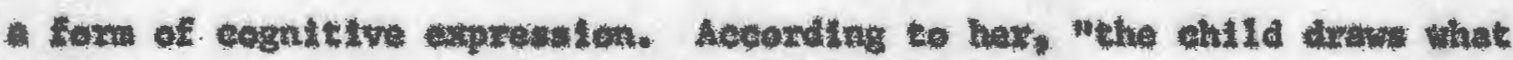

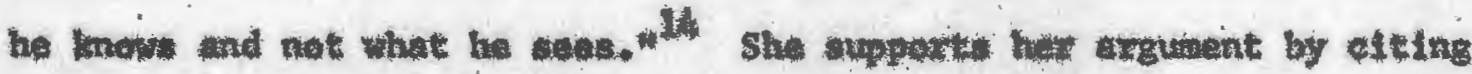

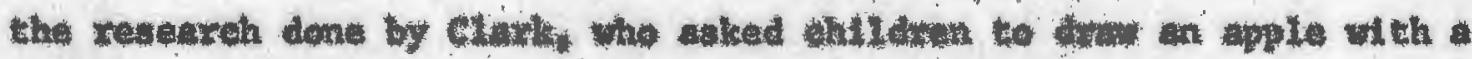

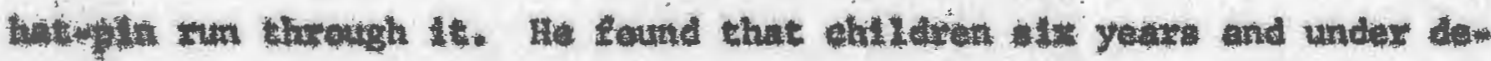
wunded that the total purt of the pla show all the vay thatugh the apple.

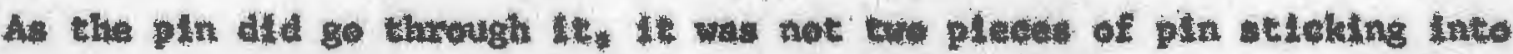

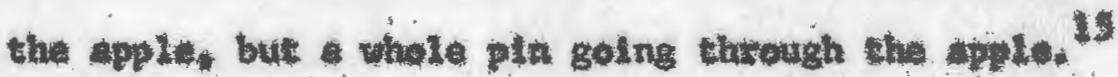

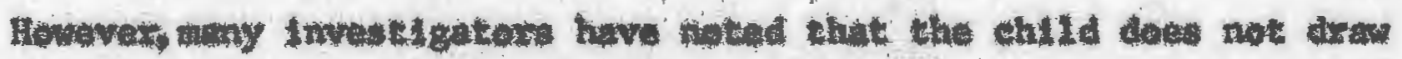

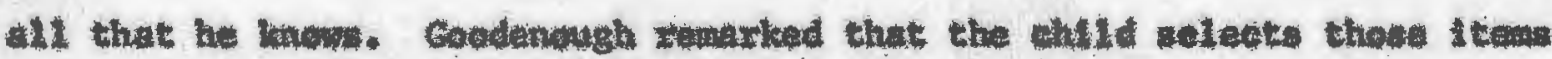

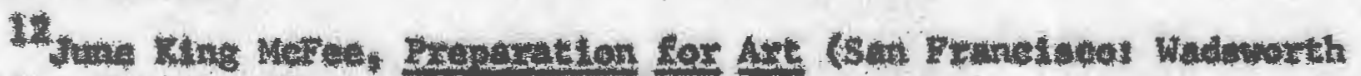

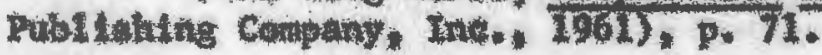

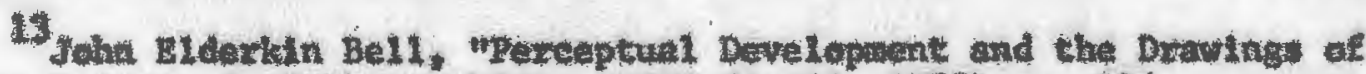

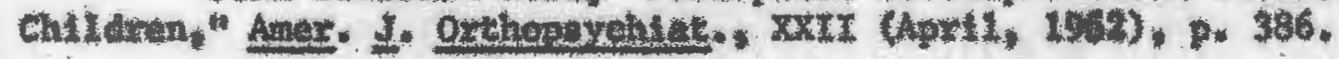

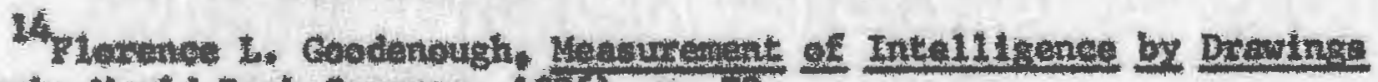

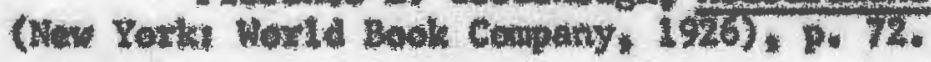

15 Studies $1 \mathrm{n}$ Educatton by Barnes. Vol. I, pp. $283-294$, st ted by

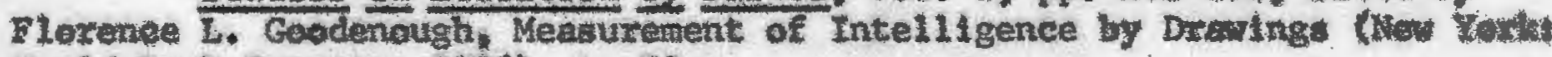
World Book Company, 1926), p. 72. 
which to hlm are so essential of chaxacterlatie that they oceur to him opontendouly without suggestion Exem outelde sources. 16

Mott" 8 itudy of 1212 dxwings made by four- to seven-year-old chlldxen revenled that when chlidxen are asked to draw particular type of man such as pollcenar or a cowboy or a farmer, It sexver to involve them

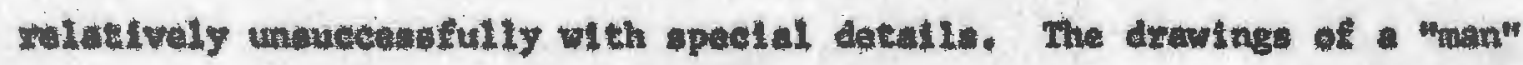
were Invariably superlor to the dratinge of a oputitled mu, 17

The problew whteh the ohlid bes to weet is priwartily one of elec-

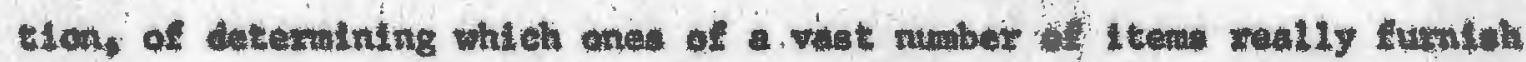
the hey to the eltuatlon. Kronladge of a foct does not in Itself gunxinu

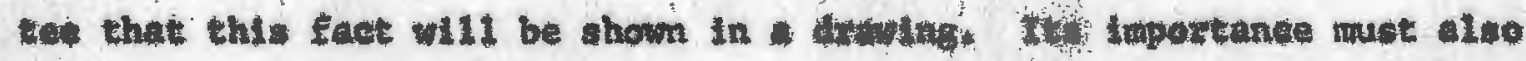

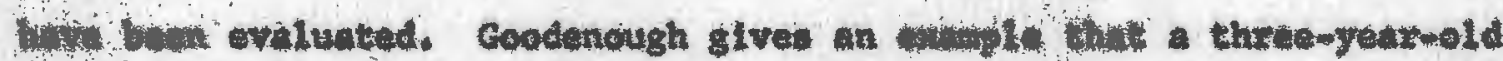
halld will polnt to hta haly when asked to do wo, but 50 pex cent of

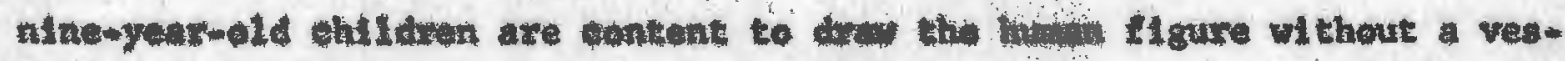
tlge of hat ${ }^{18}$

Herris brings out an tuportant potnt thet the fwetlon of draning whenge the ohild matures. He malntatns:

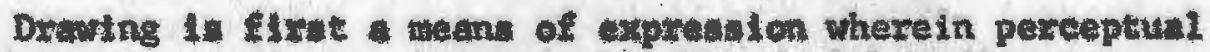
and water aspeets are inextriesbly bound with zudimentary cencept formation. In tine the motor expression aspect of draning becones less and less important; the conceptual and conaumicative aspects more and more significant. As coneupts become mere shaxpty defined and controlled by visual percepts, the ehlld"s draving of the human flgure beewes more definite, wore indicative of a clese, eype or particular Individual,

\section{Ibld p. 76 .}

${ }^{17}$ SIn M. Hott. "The Growth of, an Abutrast Conepe," Child Develen." $x$ (Mareh 1939), pp. 21-25. 


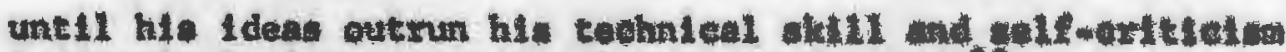
Increasingly intervenes to discourage dranthe, 10

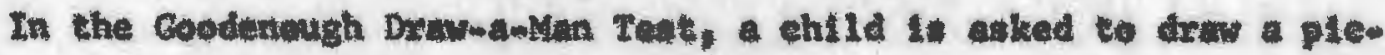

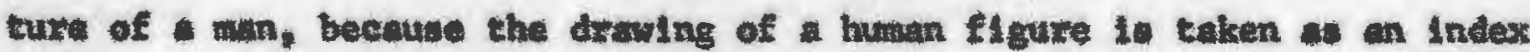
to the other complex concepte in general. It is conaldared that the chlid: eoneeptualization of the humen flgure it at much different, in

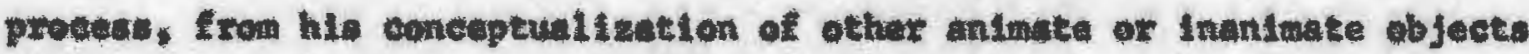
In hil expertenee. The human ftgure is so traportant for a thlts, affeetively as vell as ogniteivaty, that. It in probeble that the human itgane

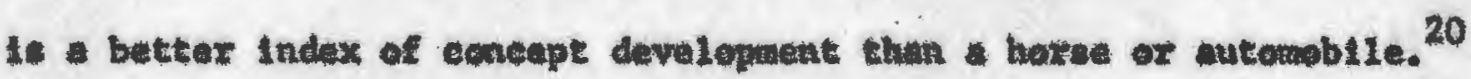

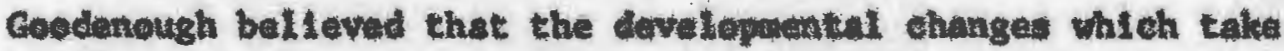

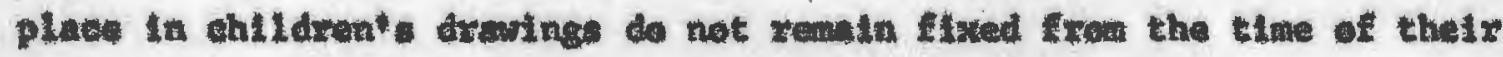
flrot appearence. Any new characteristle whose conept is not weil in-

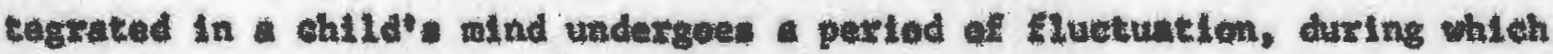
Elme It Io sewetimes thom and sometimes not. ${ }^{21}$

Graher et. al, made a study about the develepment in presehoel

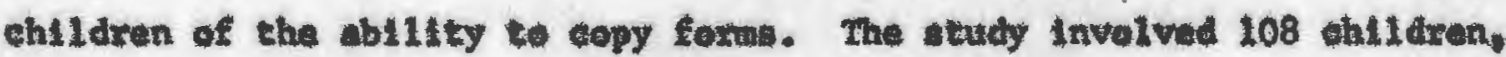
ath the age gxoup of two and a hall yearu to atx years. They suggent that rises and gallo in types of opexations represent Indiredt consequences of the gradual Improwenent in aceuracy of pexformenee. The Intexpretation

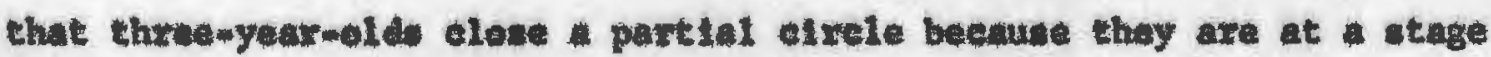
of development where there to a closure tendency te belled by the fuct

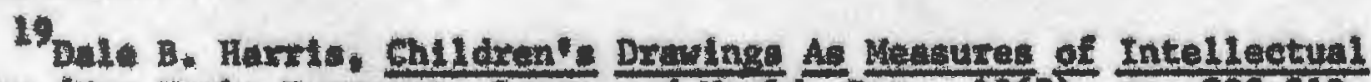

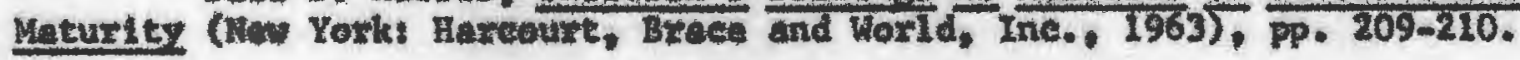
20

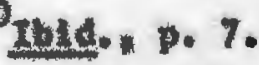

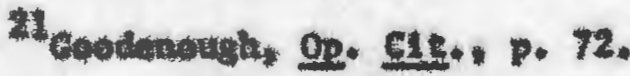




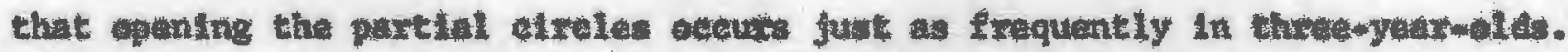
An Interpatution which does accord with the fact: Is that in the course of

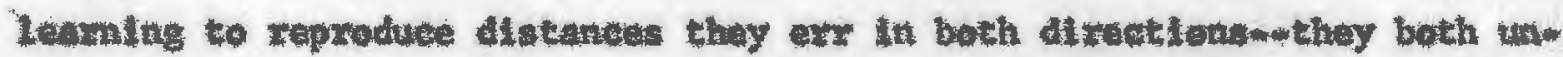
dex and overeatimate. 22

Rellability of the Coodenough Dravedkan Tet. A nuber of studles

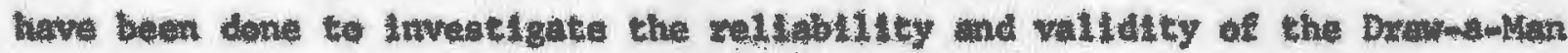

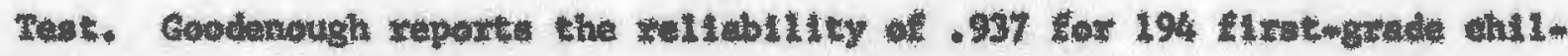
dxes reteated the fellowing day, acored by the same extentnot. The aver-

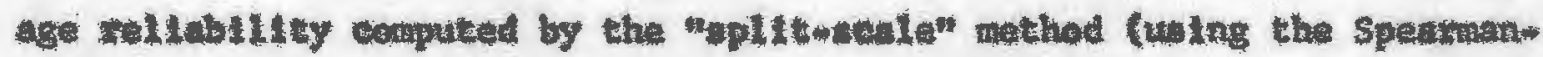

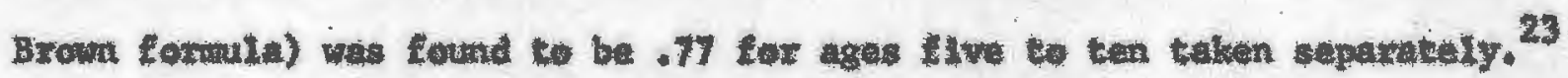

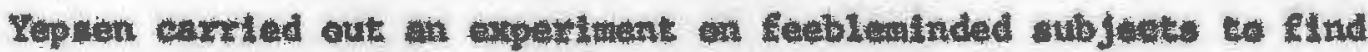

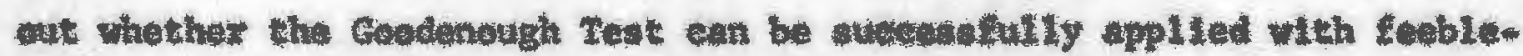
minded individuala. He gave the test to 37 beys between the agen of afne

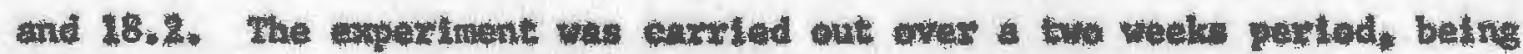
adninistered there times wth a four days intervil botween ench trial. The terules are as follerst

Between 1ot and 2nd adninistratlons the comelation .89

Between 2nd and 3rd achinistzaticas the eornelation

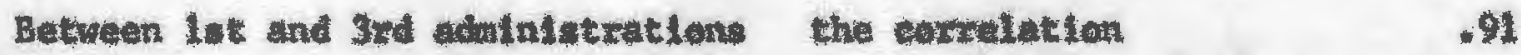

These rosults indleate the clese agremont between the wesult: ebtalned an three adninteration. 24

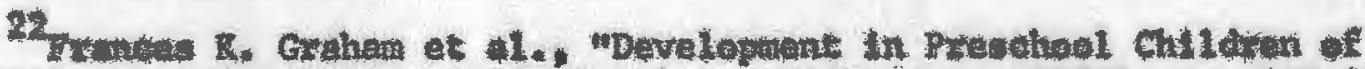

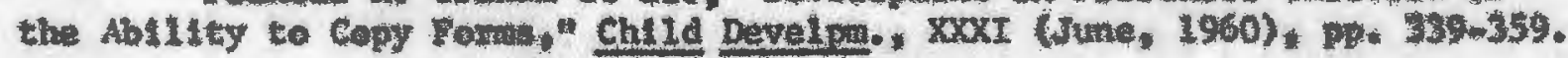

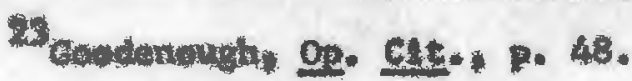

24 Lloyd N. Yepsen, whe Rellabllity of the Coodeneugh Drating Test

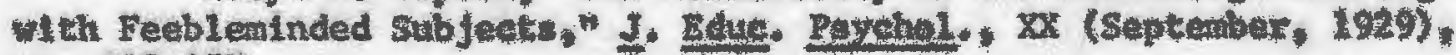
pp. 448-457. 


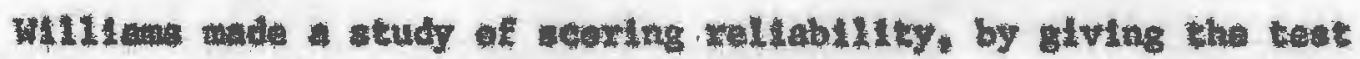
to 100 ehildren of altemble ages, whose drontings were scored by flut

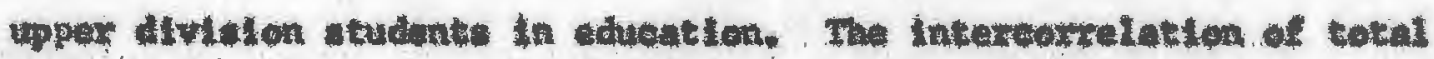
vecres ringed tzon 80 to .46 ,

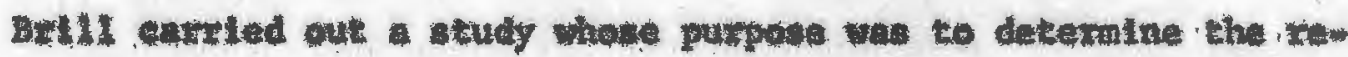

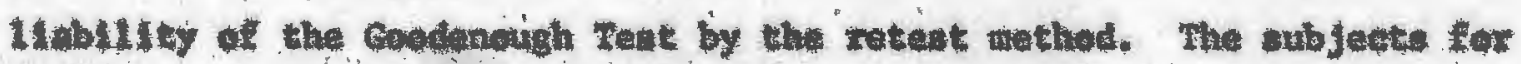

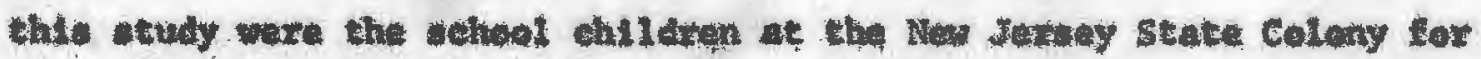

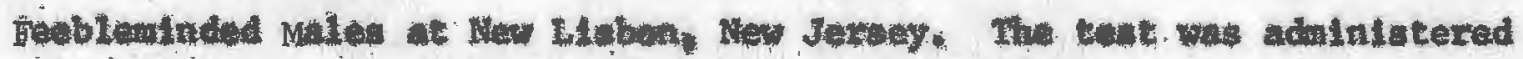

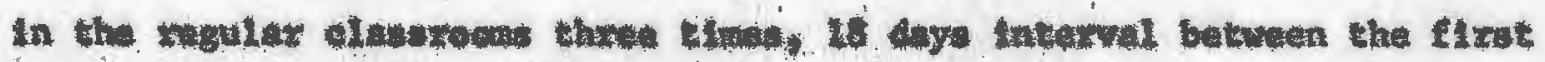

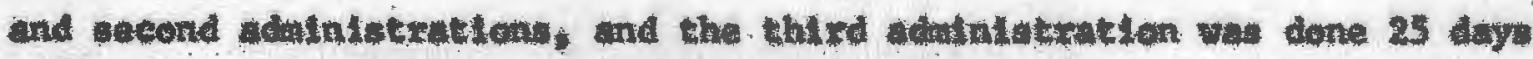

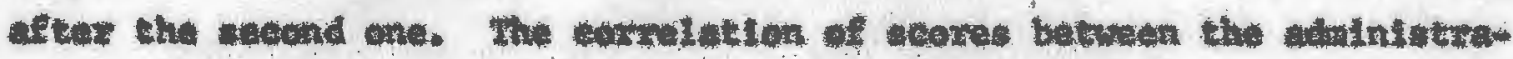
tion are folloma $(n)$

R. N

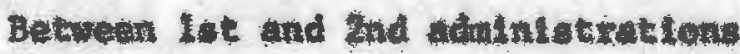
77

Betwean and $3 x d$ adatnistextetun: .8065 Betwean Itt and 3nd adminlutertion: $68.67^{26}$

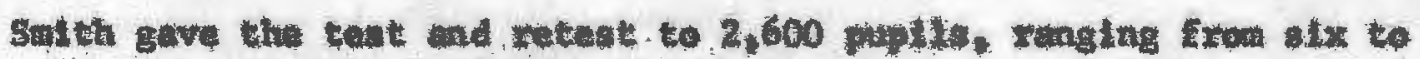
Ixteen yeaxs of age. He tound that the connelatton ranged frem .91 to .95

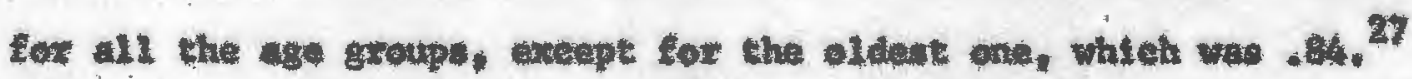

25. Howold WLLLam, "valtdity and Rellubility of the Geodenough

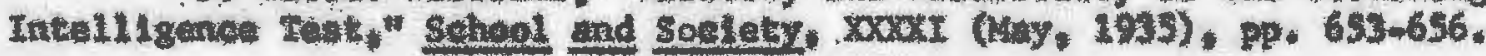

26. Brill, whe Rellability of the Coodaneugh Dramaman Teat

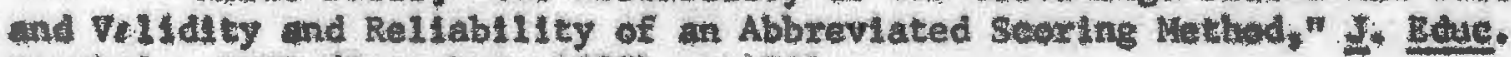
Poychal. Xavi (Decerabex, 1935), p.' 701 .

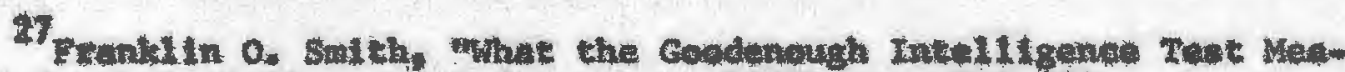

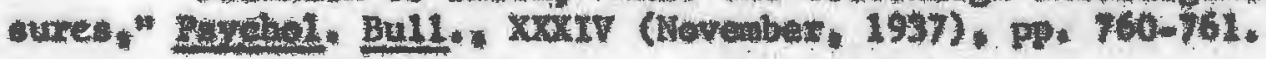


In 1944, Mecarthy conductad a study in onder to shed further 11ght on the problea of nellubility. She wentioned that the highent ratest re-

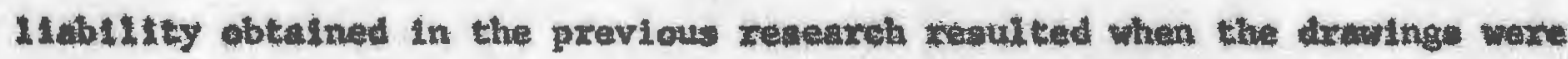
made on the asure day or success Ive days. She thmught the memory wight be

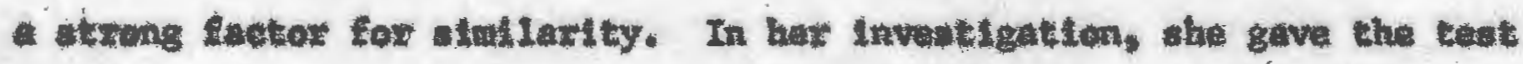

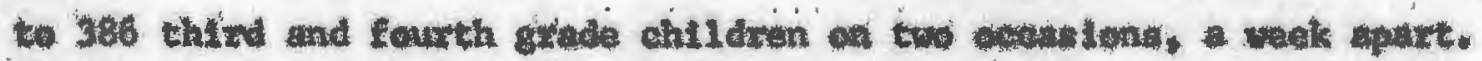

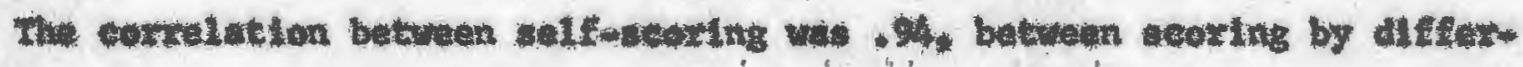

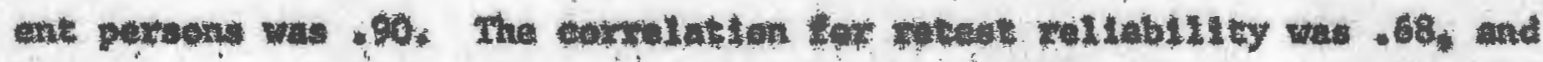

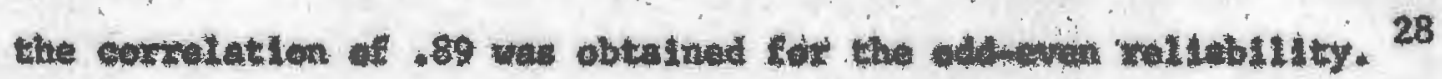

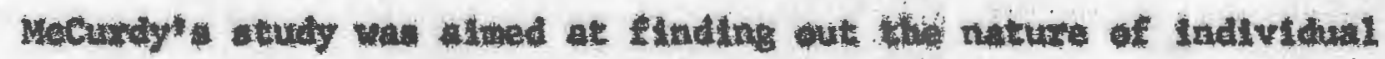

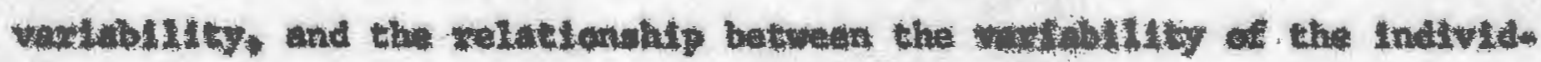

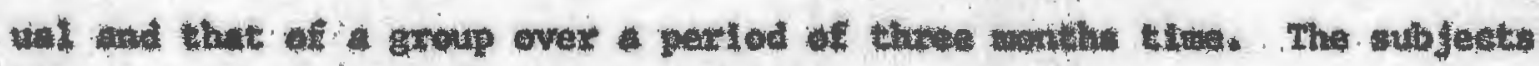

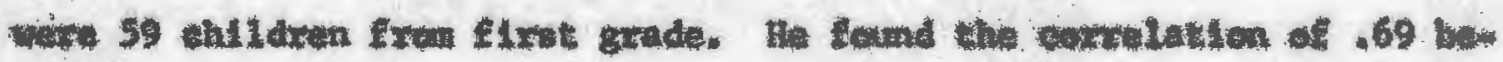

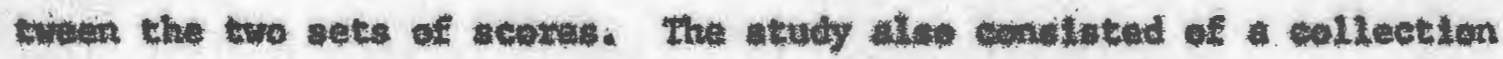

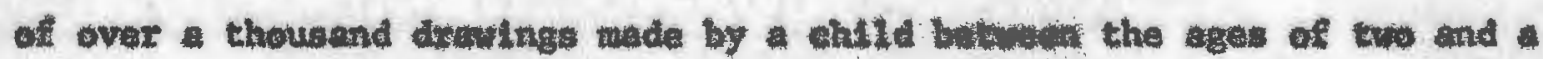

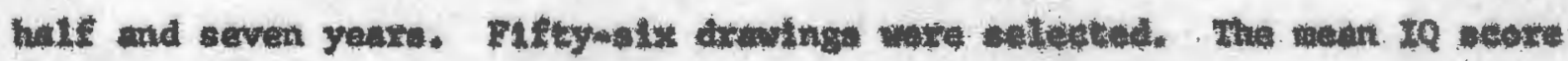

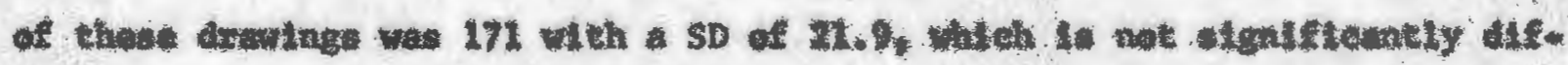

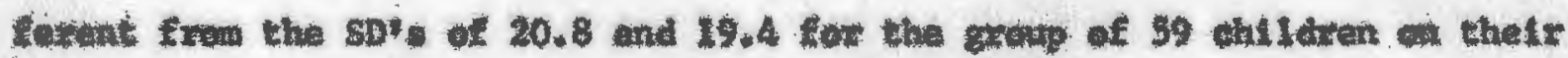

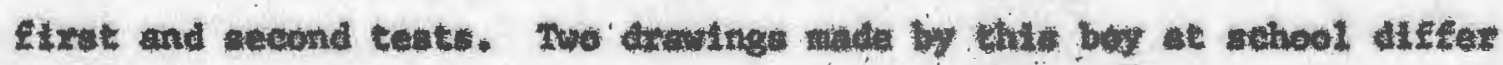

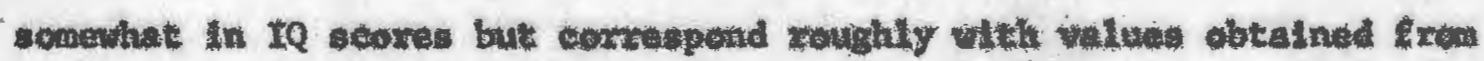

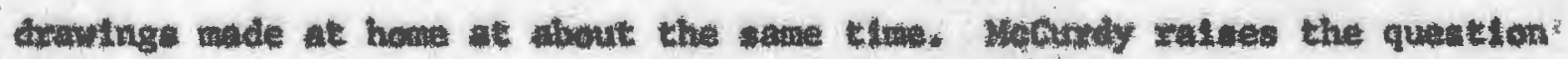

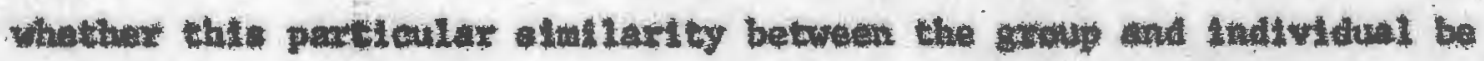

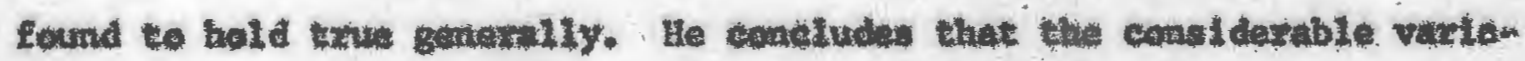

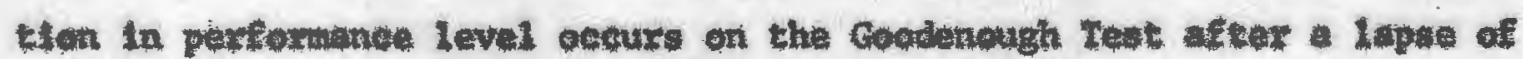

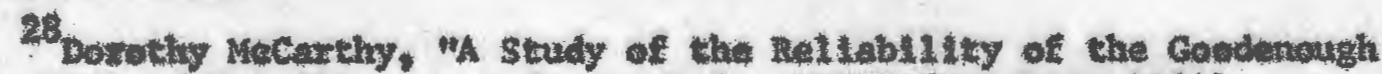

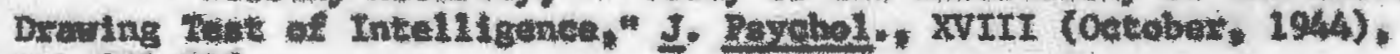
p. $201-206$. 


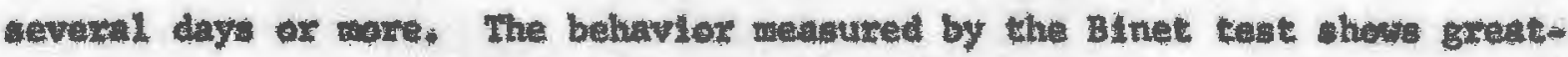
ex atabiltey, which might be due to the fagt that phyalkal coandination centributes to the Goodenough resulte. The suple functions like moter skill. Involved exhbit more varlability in general than do complax ones

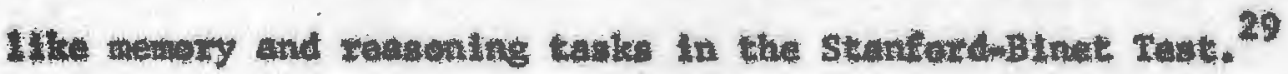

In the process of reatandardistng the Drew-aman Test, Harris stwe

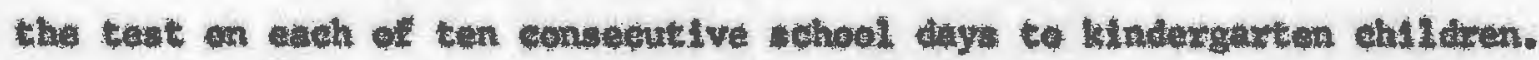
The results Indicate that the varianed accounted for by vartatien vithin the sequence of ten druting was inatguleteint. 30

These results of the relimblitty of the Geedeneugh Drum-a-Man Test are sumarized in Table it

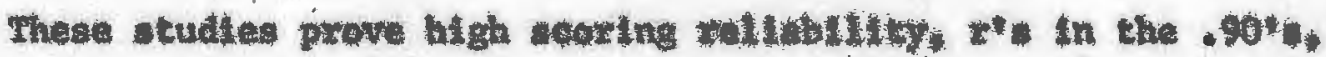

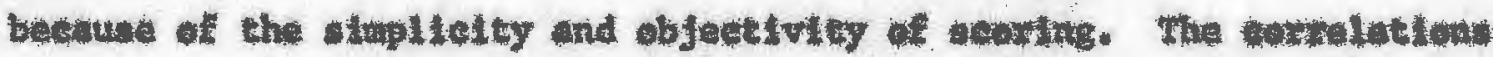

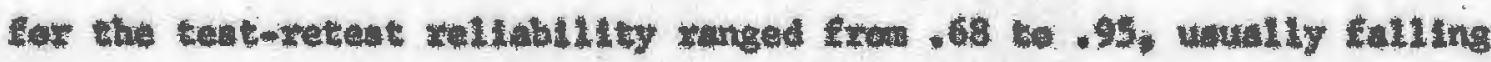

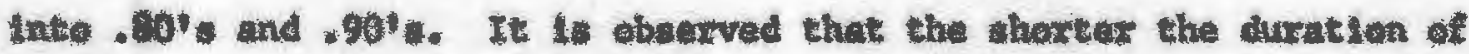
tine bstween two tents, the higher the comelation and vice verse. How over. netther age, nox intelligente lovel of chlidwen affect the correlecton oodthelent.

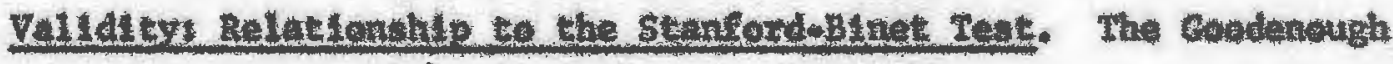

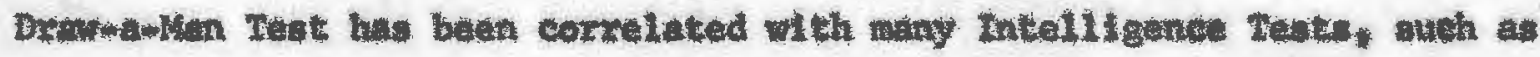

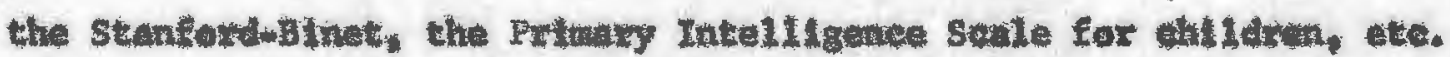

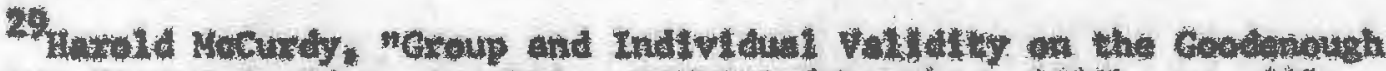

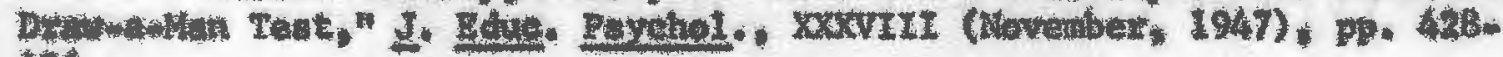
48.

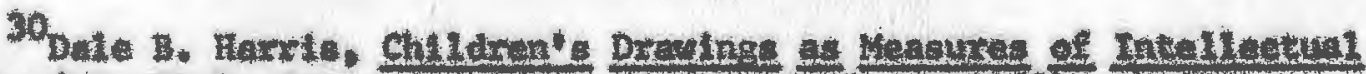

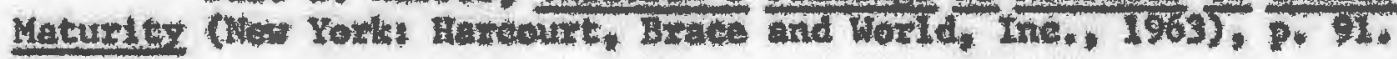


TABLI I

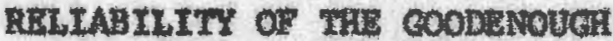
DRAM-A-XN TEST

\begin{tabular}{|c|c|c|}
\hline Antum & 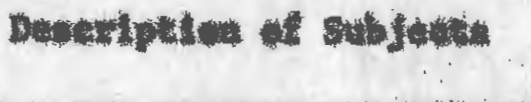 & 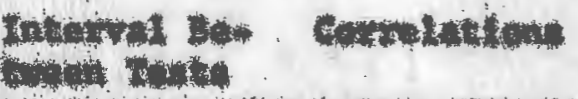 \\
\hline Condunasgh (1926) & 194. flxt-grade thl & One day \\
\hline repuen (1929) & 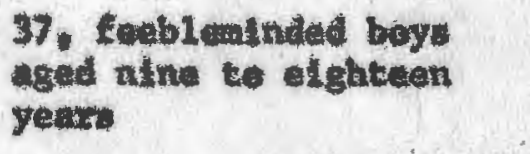 & 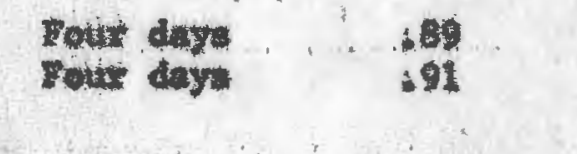 \\
\hline BxL11 (1935) & $\begin{array}{l}\text { 73. feebleminded niles } \\
65 . \text { feebleminded malo } \\
67 \text {. feebleninded anles }\end{array}$ & $\begin{array}{lr}\text { Elghteen day } & 77 \\
\text { Iwenty-flve doy } & 80 \\
\text { Six weela } & 68\end{array}$ \\
\hline suted (1937) & 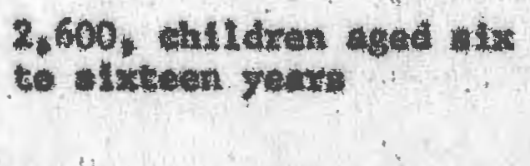 & $\begin{array}{l}\text { Betwaen } \\
.84 \text { ind } \\
.95\end{array}$ \\
\hline rofenthy (19) & $\begin{array}{l}\text { 386. thinderad fousth } \\
\text { childran }\end{array}$ & One veek \\
\hline Hotroty (194) & 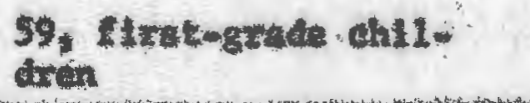 & 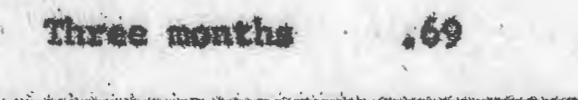 \\
\hline
\end{tabular}


Coodenough reported that 334 ehtldren were given beth the Dran-anMan Test and the stanfoxd-Binde. The average correlution between the drang ceores and Stanford-Binet wental ages was .763 for ages four to tuilve taken sepaxitaty; ${ }^{31}$

In 1929, Yepsen gave the test to 37 feebleminded boyw between the ages of wine and 18.2. and found a correlation of .60 (1Q valteo) between the Goodenough and the Stantordab inet reats. 32

Marlwee adninistered the test to 45 subnomal dhildren In the ungraded elase of New York Ctty, whe were 14 years of age, Both, the Drawa-Men Teat and the Stanferdubinet, were given at the same tima. A corselation of .72 (mental ages) was found, usling the product-matment forms$1 a^{33}$

WIIIIane" study of 100 chlldren, aged three to fifteen, ylelded the cerrelaction of $.80 \pm .024$ (mental ages) betweon the Drwawkin and BItret Tests. The corxespending cexrolation of IQ botween the two tests was $.65 \pm .038 .34$

In 1945, Mettugh gave the Drew-a-Men Test to 90 kindergarten dhlldren,

31 Mwowiee L. Coodenough, Messurement of Intel118ence by Drarings (New Yorki World Book Company, 1926), P. 50

32 Lloyd N. Tepsen. NThe Rellability of the Copdenough Druming Teat with Feebleninded subjectis" I. Educ. Paychel. Xx (Septenbex, 1929). pp. $448-457$.

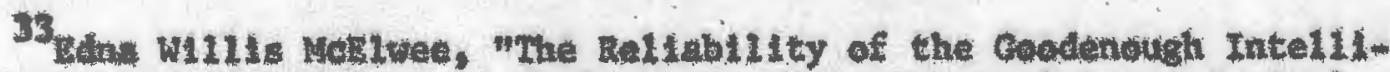
gence Test Used With Subnorwal Children Fourteen Years of Agr," I. Appl. psychal. XVt (1932), pp. 217-218.

34. Hamold W1111ams, "Valldity and Reliablitty of the Coodenough Intelligence Test," Sehaol and Soctety, xxxxI (Moy, 1935). Pp. 653-65. 
in order to find out the relationship with the 1937 revised Stanford-Binet Test. The correlation between Goodenough MA and Blnet MA was .45 , and the correlation between Goodenough IQ and Binet IQ was .41. He mentions that the reason for a low correlation was the use of the two forms of the 1937 Revision of the Binet. Mchugh also observed a definite tendency for 83 kindergarten subjects who scored initially high on the Goodenough Test to make lower scores on the second Goodenough Test and for Initially low scorers to Improve considerably on the second. 35

Estes a1. correlated the Draw-a-Man Test with the 1937 StanfordBinet and the 1960 Stanford-Binet Form L-M. The group, consisting of 82 children, attending the University of Kentucky School in grades 1 through 8, were of above average intelligence. The resulting correlation was .43 for the 1960 Stanford-Binet. The correlation is significant, but relative1y smal1. 36

In 1963, Thompson and Finley made a study on children referred for School Gutdance Services. The study was concerned with the relationship between the Goodenough Draw-a-Man Test and the Stanford-Binet Form L-M Test. The subjects were 81 boys and $83 \mathrm{~g} 1 \mathrm{rls}$, enrolled in kindergarten through grade 3 and had a mean age of 75.4 months with a range from five years to nine years. A correlation of .67 was found between the IQ'B of

${ }^{35}$ Gelolo Mcliugh, "Changes in Goodenough IQ at the Public School Kindergarten Level," J. Educ. Psychol., XXXVI (January, 1945), Pp. 17-30.

${ }^{36}$ Betsy Worth Estes et a1., "Relationshtp between 1960 StanfordBinet, 1937 Stanford-Binet, WISC, Raven and Draw-a-Man," J. Consult. Psychol., XXV (October, 1961), PP. 388-391. 
the Stanford-Binet and Goodenough Draw-a-Man Tewt. ${ }^{37}$

Kennedy and Lindnex made a study on the Nagro population of the Southeast UnIted States. The purpose was twofold: 1) te extablish badly needed normative data for routtriely used elinical Inatruments on Negro populatton; and 2) to detexwine the effectiveness of the coodenough Drew-a-Men Test in relation to other IQ scores. The subjects were 1,800 Negro elewentary achool chlldren. The correlation bntwmin the two tests. Blnat and Goodenough ranged from a high of .39 at grede. I to a low of .29 4 trade $40^{38}$

The reaults of the relationshtp between the Goodenough Dran-k-Man Test and the Stanford-BInet Test are suanurised In Table II.

The studies show that higher eorrelation were obtalned when the correlations were computed with stenford-Binet wattal age, than the correLations computed with Binet IQ. The eprrelatiens ranged between .40 and .80 , and sometimes as low as .29 as an exception. Thus, In general, the Dran-a-Man Test correlates as vell with the Stanford-Binet as othur tests of intelligente.

All the studies mentioned regarding rellabllity and valldity of the Goodenough Draw-B-Man Test are done for the 1926 version of the Drew-awan Test. No study has been found for the 1963 Revised Goodenough-Harris DrawIng Test.

37 Jeck H. Thempson and Carmen J. Finley, "The Relettonthip between the Goodenough Draw-a-Man Tast and the Stanford-Binet Form L-M In ChIldren Referred for School Guldance Services," Callf. I. Bduc. Res.. XIV (1963), Pp. 19-22.

38. Wallage A. Kennedy and Ronald S. Lindner, MA Nomative study of the Goodenough Draw-a-Man Test to Southern Negro Elementary School Children," Child Develpm., : XXXV (Maxch, 1964), Pp. 33-62. 
TABLE II

VALIDIT: RELATONSHTP TO THE

STANORD-BINET TRST

Godenough (1926)

334, ehildxen egel alne to

.763 (na valued) tulve yexis

Tepenen (19z9)

37. Institutionalized

.60 (IQ vilutus) mentally retarded boys, aged nine to elghteen yeati.

wattre (1932)

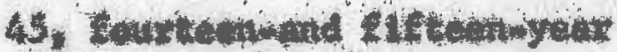

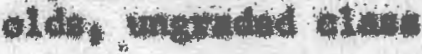

.72 (M values)

W1114tan (1935)

100 , dhildxen iged three to Elfteen yaurs, crbandanal of gifted

Mallugh (1945)

90. Rundergenten andldren

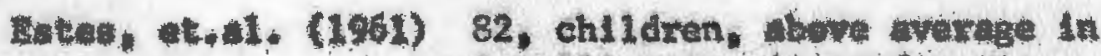
intelligence, in gritles pira through elght

Thonoten and Finley 164, ohtldxen aged ffve be the (iest)

renudey and Lthơnex (a)4)

1,800, Nogxo thildxwa in grades one through tax
.80 (MA values)

.65 (IQ values)

.45 (M vilues)

.41 (to valites)

45 (IQ values)

.67 (to values)

Between

.29 and

.59 (14 values) 
The Gosdenough Drem-g-Men Teat has proved to be rallable ond velld. SInea the Goodenough-llarris Draulng reat is se new, this atudy is an explosetaky one to detarmine ite chemeteriatstes. 


\section{III}

SUBJECTS ATD PROCEDURS

In this sectlon, the abjecte etudied and the procedure, follomed for this atudy will be distuased.

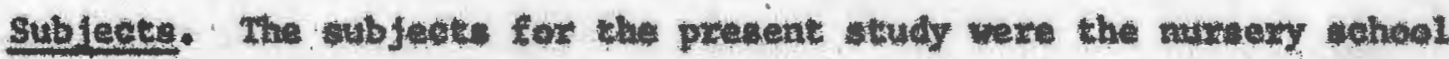

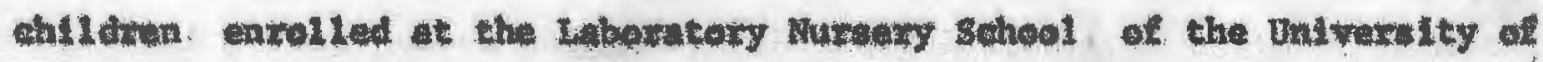

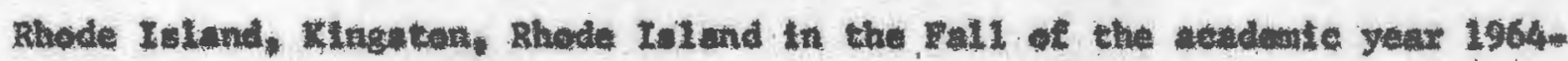
1965. The total number of the subjects was thirty, wh equal numbers of

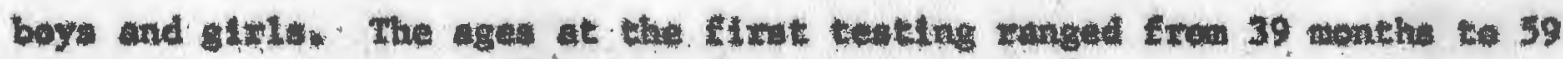

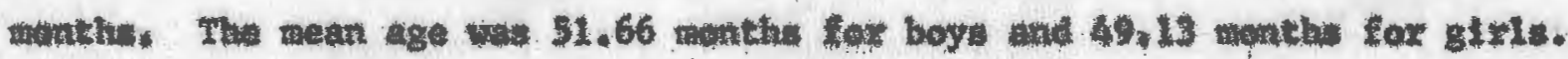

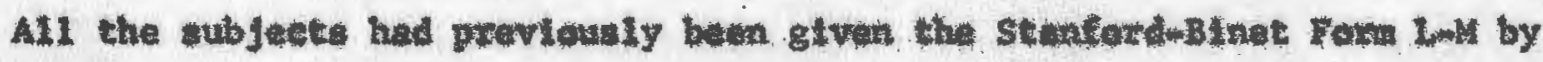

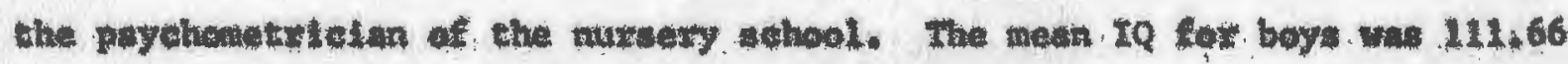
and 121.85 fore gtale.

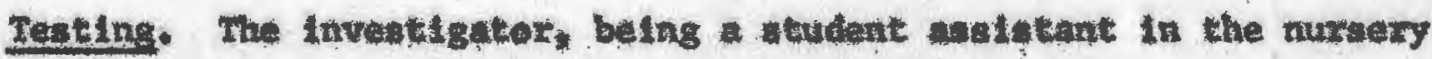

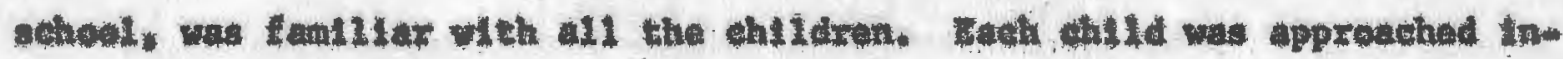
dividally and was asked to go and play a game wt th the Investigator in the keating roow of the nuratxy whool. Bach thild was give the crodenoughw

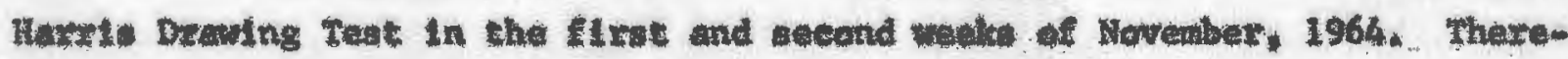

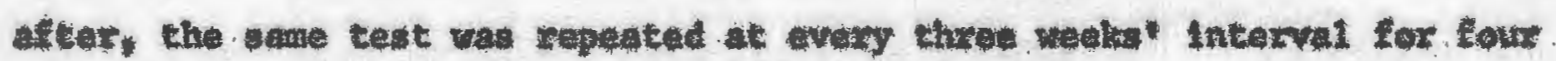

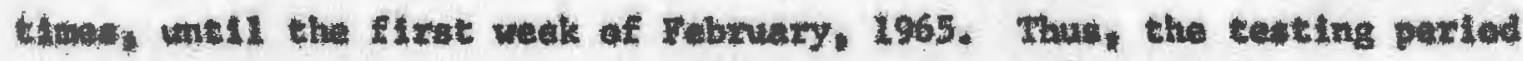
covered thirteen weeks.

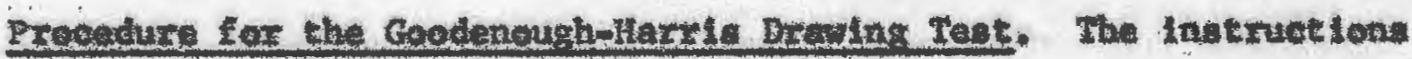


given by fiaris in the rovised Test Manull were followed. ${ }^{1}$ gach ehild

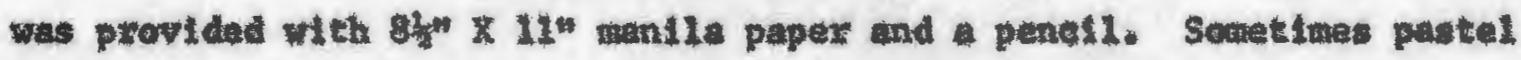
colored puper was given for varlety in order to malntala Interevt and to avold the bexteden of playing the sume game every three weoke.

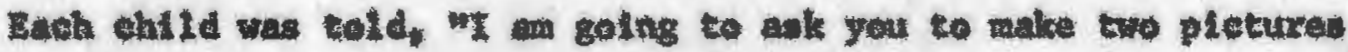
for me today. Ifret, I wat you to make a pleture of a man. Make the very best pietrize that you can wake. Be sure to wilke the thole man."

The draning was praised, and the child wa encouraged to drat a pheture of a wonan. He was told, nThie time I wat you to make a pleture

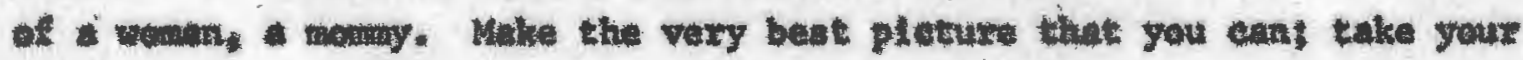
the and woxk way cartully. Be sure to make the whole woman."

Aftex the dwanting was cempleced, It was protiod lavinhty. This,

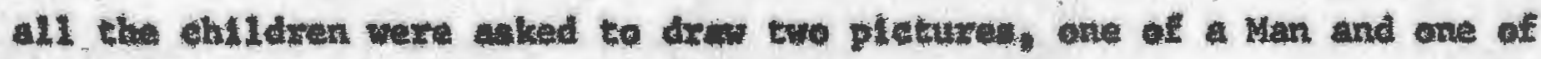

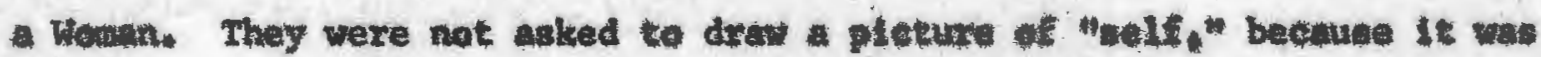

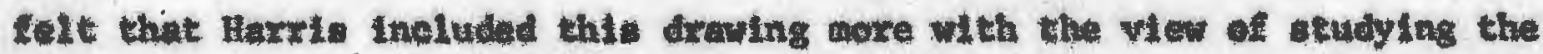
alf-bongept and to wee as a prejective devide ter the study of affect

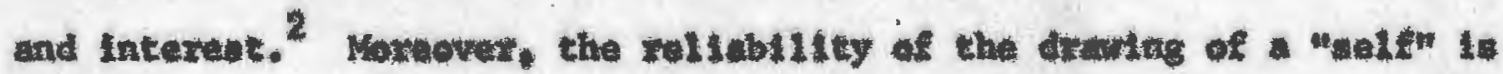
not evaluated by compaxing it with Man and Woman drawings.

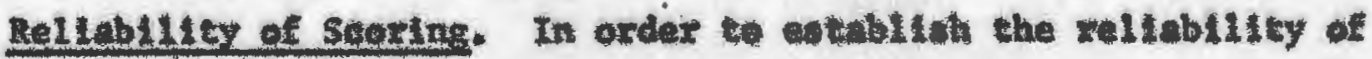

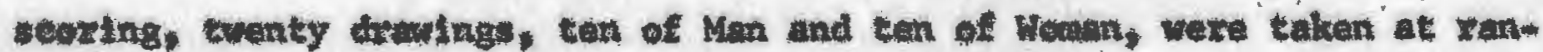

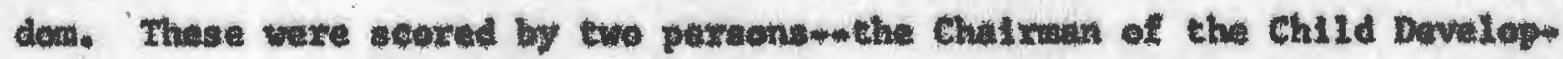
ment Department and the Investigatar.

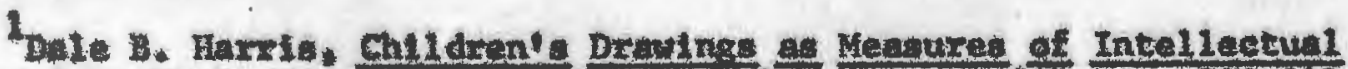
Maturtty (Nes Yorki Bareart, Bkace and World, Inc., 1963), Pp. 239-240.

20te. p. 8. 
Twe apprenthe were taken In evaluating the zeliebiltty. In the timet approach, the disagreenent was counted Iten by Item, wheh rowulted In 3.5 per ent of total dinagwewent on all twenty drowings.

Anothor appraseh to eveluating rellabulity to through correlating

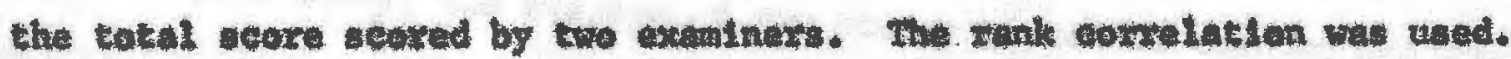
The the obtalned for the Man Seale vas 99 and for the Women Soule. 98. The resulte Indleated that a high level of agraement was obtaland.

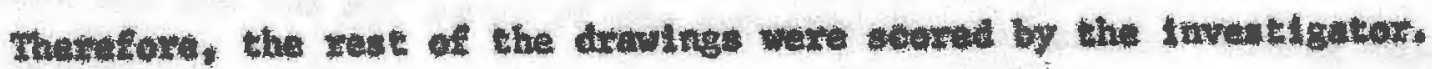


TABLE III

RESULTS OF THE GOODENOUGH-HARRIS SCORES ON FIVE TESTINES

(AVERAGB OF MAN AND WOMAN RAW SCORES)

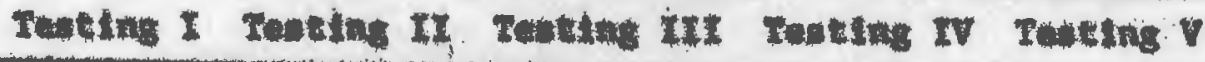

\begin{tabular}{|c|c|c|c|c|c|c|}
\hline $\begin{array}{ll}\text { Testing II } \\
\text { Testing III } \\
\text { Testing IV } \\
\text { Testing } V\end{array}$ & $\begin{array}{l}x= \\
x= \\
x=\end{array}$ & $\begin{array}{l}.898 \\
.870 \\
.813 \\
.766\end{array}$ & $\begin{array}{l}.936 \\
.826 \\
.815\end{array}$ & $\begin{array}{r}.819 \\
.820\end{array}$ & .927 & \\
\hline $\begin{array}{l}\text { Range } \\
\text { Mean } \\
\text { SD }\end{array}$ & & $\begin{array}{r}0-19.5 \\
8.2 \\
4.9\end{array}$ & $\begin{array}{r}0-21.0 \\
9.0 \\
5.0\end{array}$ & $\begin{array}{r}0.22 .5 \\
8.6 \\
4.4\end{array}$ & $\begin{array}{r}2-20 \\
10.0 \\
4.6\end{array}$ & $\begin{array}{r}3-19.5 \\
11.3 \\
4.4\end{array}$ \\
\hline
\end{tabular}

research resulted when the drantng were made on the same or consecutive days. I Therie is evidence that when Goodenough gave the reteat on the followIng dxy, the correlation of .937 was obtalned. ${ }^{2}$ the study of Mecurdy ylelded the earrelation of .69 because the retesting was done after three watho ${ }^{3}$ The reaults of thls atudy aupports the sect polnted out by MeCarthy; 4

The SD's of the scores on tive tentings range fxom 4.4 to 3.0 . The test of homggenelty of varianee showed that the difference between the SD'a of sceres on five teatings Is Inulgafleant.

Change of Seores Betreen Consecutive Paire of Testings and Between the First and lost Testinge. Table IV presents the change of scores between test. and retests. The mean difference between each consecutive pair

IDowthe MoCerthy, "A study of the Rallability of the Goodenough Drawing Teat of Intelligence," I. Purchol. XVIII (0etober, 1944), pp. 201206.

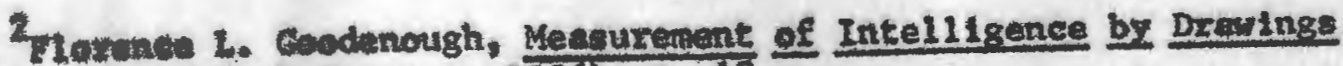
(Hew Yorki World Book Company, 1926), P. 48.

3 Haxuld Mecurdy, "Group and Individual Valldity on the Goodeneugh

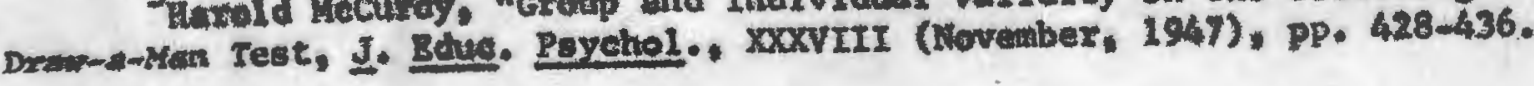


of teats and betwaen the f1rat and leat test was camputed. Each time there was on luoreane in the mean score except between restinge II and III, when theze was a meen decrease of 4 . The "t)" teat was computed in order

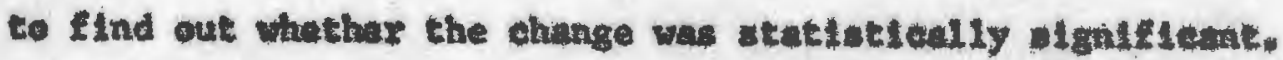

The table of "t" distribution sndicates that the increase between Tentings I and II, and the decrease between renting II and III are inilgntflemt at the .05 level. But the differdives ytelded between reatinge III and IV, Teot: IV and $V$ and Teatinga I nd $V$ algnifieant at the .01 1ever,

\section{TABIE IV}

CRANEE OF AVERACE RAW SCORES BETWEEN CONSECUTIVE

PAIRS OF TESTINGS AM BETWEEN TEE

FIRST AND LAST TESTHES

\begin{tabular}{|c|c|c|c|c|c|}
\hline$p+1$ & $\begin{array}{l}\text { Betroen } \\
\text { Batting } \\
\text { I and II }\end{array}$ & $\begin{array}{l}\text { gabuen } \\
\text { Tutalng: } \\
\text { II and III }\end{array}$ & $\begin{array}{l}\text { Benceen } \\
\text { Tenting } \\
\text { IIX and IV }\end{array}$ & $\begin{array}{l}\text { Betreen } \\
\text { rentingt } \\
\text { TV and V }\end{array}$ & 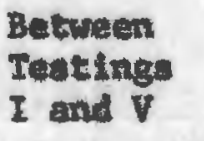 \\
\hline $\begin{array}{l}\text { Mean differened } \\
\text { tet }\end{array}$ & $\begin{array}{c}0.83 \\
2.0 \\
\text { nowiste } \\
\text { aifleant }\end{array}$ & $\begin{array}{c}-0.40 \\
-1.21 \\
\text { non-1. } \\
\text { nifleant }\end{array}$ & $\begin{array}{l}2.4 \\
2.9 \\
\text { stgntifteat } \\
\text { at the ol } \\
\text { level }\end{array}$ & $\begin{array}{l}\text { 1.3 } \\
4.0 \\
\text { Stgalk ient } \\
\text { at the } 01 \\
\text { leval }\end{array}$ & $\begin{array}{l}3.1 \\
5.4 \\
\text { stgndf1- } \\
\text { eant at } \\
\text { the ol } \\
\text { level }\end{array}$ \\
\hline
\end{tabular}

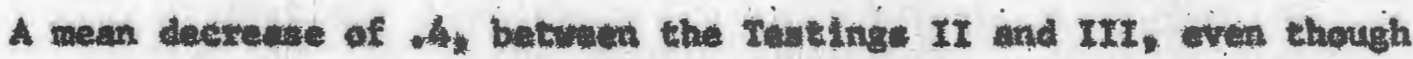
Indgntflent: ouggents the posolbility that this wight have been bacase the thixd teating was done curing two weeks prior to the Chrintmes Vecation. At that the, many new activitles, lihe anking christma cards and docera. thend, vere golng on in the nursery school. This attraeted the chlldren's interest and the chlldren were leas Interested to go and play a game with the invertigater. 
The significant rise in scores from Testing III onwards suggests the possibility of practloe effect. It seens that as the chlidren made the pictures of Man and Woman thrte Efmes, they Improved wth practioes. and therefore were able to make better ptetures.

The IndIvidual scoring on Elve testings showed that five chlidren showed stablity on the scores of four testings out of five. Their score did not vary wore than \pm 1.5 esch time. On the other hand, five ehildren showed Inatablifty on the scores. Their scores varled more than $\pm 1.5 \mathrm{on}$ four teatings. Scae of the Information regarding these eh1ldren is provided belew:

Mornlng Group of Chlidxen:

Children with stable Seores

Sex Age in $\quad S-B$ IQ

$1 \quad \mathbf{F}$

42

104
Children with Unstable Scores

Sex Age in Months

$\begin{array}{rrrr}1 & & 46 & 136 \\ 2 & M & 58 & 128 \\ 3 & M & 48 & 86\end{array}$

Afternoon Group of Chlldren:

Children with Stable Scores

Age in $S-B$ IQ
Months

$\begin{array}{rrrr}1 & F & 44 & 140 \\ 2 & F & 49 & 121 \\ 3 & M & 48 & 119 \\ 4 & M & 57 & 97\end{array}$

Chlldren with thstable seores

$$
\text { Sex Age in } S-B \text { IQ }
$$
Months

$\begin{array}{llll}1 & F & 58 & 116 \\ 2 & F & 48 & 136\end{array}$

Frow the above date, It seems that stab111ty and instability of scores do not have any relationship with IQ or age or sex. The two head teachers of the merning and afternoon groups were asked whether they found any difference in the peraonality of these children. The teachers did not know the 
scores of these children. The moxning group teacher could not see any differenee. But the teacher in the aftemoon group thought that the two girle tho shomed inptability on the scores are unsure of themselves and feel Insecure at tuate. On the other hand, chlidren the showed atabiltty a the scarew, all but one are sure af themelves and feel seeure. It is Inortant to polnt out that this to junt a quick judgewent on the spot; 8tven by the teachars. Pexthps a study of the pernenalitie of chlidren in relation to stablilty and Instability on seores would thren wore 11 ght.

Belationuhtp Betreen Man and Woman Sedes. The productmmonent:

correlation were calculated by the codputex for Man and Woman Ra Seoxes on all tive tentings. The remulta axe presented ti Table $v$. It is sean that all the correlation are high, ovex .85. The mean of all the wercla* thon: 18.88. All the rewults were algnifleant at the 01 level.

TABLE $v$

CORRELATION BETWEEN MAN ART WOMAN RAH SCORES ON THE FIVE TESTINES

\begin{tabular}{cccccccc}
\hline & Teating & Teating II & Teating III & Tenting IV & Testing V Meen \\
\hline 5 & .86 & .90 & .88 & .83 & .92 & .88 \\
\hline
\end{tabular}

SIgalfledat at the .01 level

The reaults show a high relationchip between the Mun and Woman seales. Haxts found out the eaxzelation of .75 when be adminlstered the thet to 1,400 abjecta, $6,8,10,12$ and 14 year old, He coneludes that a corraletion of .75 between two rellabie form of the same teat scems rathex 10w, which suggests that pexhaps different abllitles are measured by the Nan and Wonan Seales. A detalled otudy, Indteating fegter analysen of both seales" 
Itens alght be inderutive. 5

The higher correlations obtained in this study than trarris's might be due to the differanee in the age groups of the subjecte. There is a posalbility that in the dranngs of younger ohlldren there is not anch Aiffarance betwean the Agures of Man and Wown and therefore, the corxem Lation betwen two secles tend to be higher in this study. The recult: suggeat that the "Wonan" Scele can be used an an "al ternate" form for the preachool age gxoup.

Relatloughlp With Stanford-Blnt. The product-monent corralation of Ra Scores of the Drusing Test and the Stanford-Binet IQ and wental age were culeulated by the eorputer. The scores of Test I and $V$ of the Deawing Twat were wad. The renults are shom in Table VI.

\section{TABLE VI}

CORRELATTONS BETWEEN RAW SEORES OF DRAWING

TEST AND IQ AND MENTAL AGB

OF STANFORD-BINET

\begin{tabular}{|c|c|c|c|c|}
\hline & & & Blat IQ & netute nt \\
\hline $\begin{array}{l}\text { Tane } 1 \\
\text { Teet } 7\end{array}$ & $\begin{array}{l}\text { Rut Stexte } \\
\text { Rew Stores }\end{array}$ & $5=$ & .554 & $\begin{array}{r}.798 \\
781\end{array}$ \\
\hline
\end{tabular}

sintheme ot the .01 leval

The result shen thut a higher relationohip is obteined whan the raw seores are cernelated with stentordmbinet mental age than stunford-

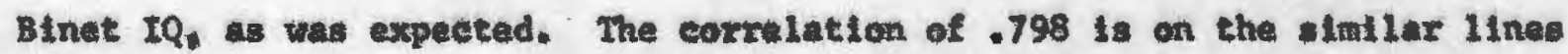

BdL B. Hatris, Chlldren's Dreings as Medsuxed of Intellectual Maturity (Now Yorkt Hareourt, Bxaw and World, Ine., 1963), Pp. 106-107. 
With the results of the previous studies done by Goodenough ${ }^{6}$ and Merlwee. 7 The correlation of .554 between the average raw scores of the Drawing Test I and IQ of Binet and the correlation of .551 between the average raw scores of the Drawing Test $v$ and the IQ of Binet are not high, although they are simflar to the results of the prevlous research done with thls age group ox the age group closer to this. Pexhap, a higher correlation would have been obtained, if both the tests--Stanford-Binet and the Drawing Test were given at the same time.

Relat longhle Between the Scores on the Inttial Test and the Amount of Change at the End of Flve Teate. The median score on the inftial test and the pedian amount of ehange between the first and fifth tests were calcu1ated. These figures were 7.75 and 2.5 , reepectively. The median test was perfexmed. 8 The results are presented in Table vir.

\section{TABLE VII}

RELATTONSHIP BETEEN THE SCORES ON TRE INITLAL TEST AND AMOUNT OF CHANGE

Above Medtan

Change in Scores
Below Medlan

Change in Scores
Above Median Score on InItial Test

Below Meditan Score on InItial Test
6

9
$\operatorname{Cnt}{ }^{2}-1.2$ Not Sigaiflcant

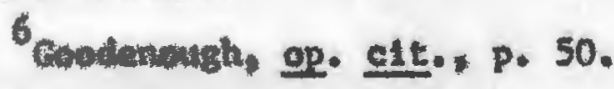

${ }^{7}$ gine Willis Mosiwee, "The Reliablitty of the Goodenough Intelligence Test Jaed with Subnomal Children Fourteen Years of Age," J. Appl. Paychal., XVI (1932), pp. 217-218.

8irglnta t. Senders, Measurement and Statistics (Nen Yorki Oxford University Pruat, 1958), pp. 446-448. 
From the bove table it is seen that eighteen ehildren show a negativo milationohtp. Nine ehildren who were below the median on the Indtal test gained an abount above the wedlan; and nine who were above the median on the Inltial tet, shomed en amount of thage below the median.

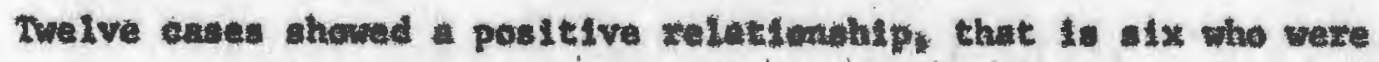
higher on the InItlal test ahowed obove avexage thange and alx who were low a the Inletial cest showed charge, which wee betes the wedtan.

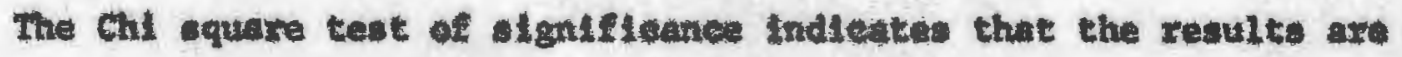
Intigateleant at the .0S Iuvi.

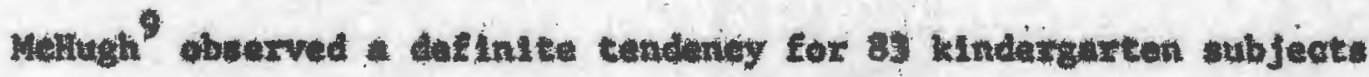
who scoxed Inttially high on the codenough Teat to make lewer scores on the

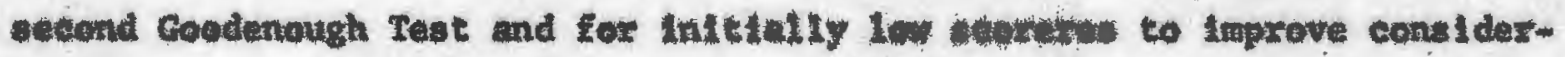
ably on the second. He did not ues the median teat but the tendency of

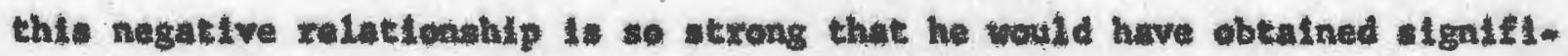
cant regults 12 he bad uned the wedian tent.

Cualetengy of Teat Itepes, The data tridteated that when partleular

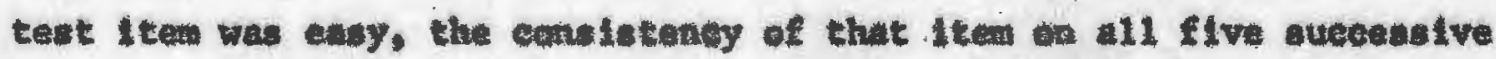
teata was gxeater, and the traquenty of non-appoaxance of that itan was lese. Convoraly, when the Item was diffienle, the ommintency of that Itew was 10e, and tha frequency of the non-appearance of that Iten was more. Tables

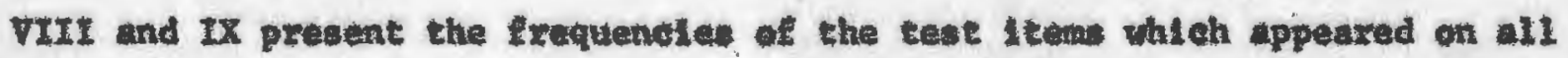
five teats and thase which did not appear on any of the Ifve tests, for the Man and Woman scales, roppettvely.

Gelolo Merrugh, "Changes in Coodenough IQ at the Publle sehool Xinder-

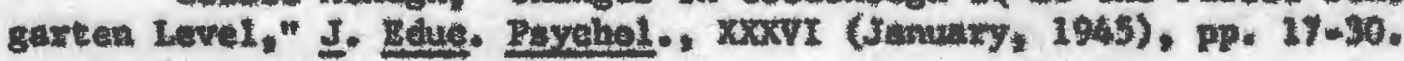


TABLE VIII

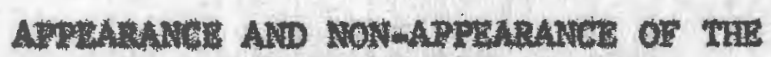
rest Imens os FIV Testucs

(POR MA SCALE)

\begin{tabular}{|c|c|c|c|}
\hline Wence of the Item & 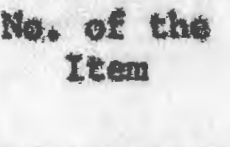 & 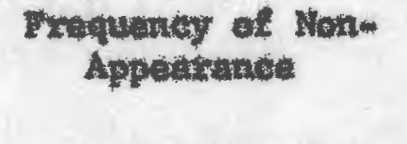 & 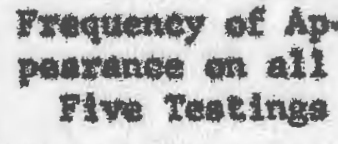 \\
\hline Read & 1 & $z$ & 19 \\
\hline Neck & 2 & 20 & 3 \\
\hline Eyee & 4 & 0 & 24 \\
\hline Bun ax Lashea & 5 & 16 & 0 \\
\hline Eye deta11. pupt1 & 6 & 28 & 0 \\
\hline Eye detal1, propert len & 7 & 28 & 0 \\
\hline Dese & 9 & $\$$ & 13 \\
\hline Bates two dinanafast & 10 & 29 & 0 \\
\hline Manta & 11 & 1 & 16 \\
\hline Fonathuted ard chlt sham & 14 & 8 & 4 \\
\hline Hat: & 18 & 7 & 3 \\
\hline Hatx $\mathbf{x t}$ & 19 & 26 & 0 \\
\hline Eares & 29 & 12 & 2 \\
\hline Eaxi preportion & 23 & 28 & 0 \\
\hline Ptuget preant & 24 & 15 & 悉 \\
\hline Kands & 20 & 19 & 1 \\
\hline Axmi & 30 & 5 & tu \\
\hline Awnos at alde & 30 & 28 & 0 \\
\hline Ibam jotnt aban & $3+$ & 28 & 0 \\
\hline Lege & 35 & 2 & 21 \\
\hline Feet & 39 & 7 & 10 \\
\hline Peat proportion & 40 & 26 & 1 \\
\hline Foet III heel & 4 & 29 & 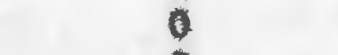 \\
\hline Peet $V$ detall & 43 & 28 & $\theta$ \\
\hline Attagtment of amas and lng. & 4 & 15 & 3 \\
\hline Trank & 46 & 6 & 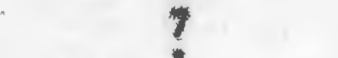 \\
\hline trunk proportion & 47 & 11 & 1 \\
\hline Head parporelan & 48 & 19 & 1 \\
\hline Paee proportion & 50 & 4 & 5 \\
\hline Axtus propertion & 51 & 25 & 0 \\
\hline Legs proportion & 93 & 4 & 0 \\
\hline Limbs tor divenstan & 34 & 24 & 4 \\
\hline clothing $I$ & 55 & 18 & 0 \\
\hline clothtng Ix & 56 & 29 & 0 \\
\hline Motor Coondinations Ines & 63 & 29 & 0 \\
\hline Wodultus techandque & 71 & 29 & 0 \\
\hline
\end{tabular}


TABLE IX

APPEARANCE AND NON-APPEARANCE OT THE

TEST ITMSS ON FIVE TESTINGS

(TOR WOMAN SCALE)

\begin{tabular}{|c|c|c|c|}
\hline Nime of the Itean & $\begin{array}{l}\text { No. of the } \\
\text { Iten }\end{array}$ & $\begin{array}{l}\text { Frequeney of Kon- } \\
\text { Appantanee }\end{array}$ & $\begin{array}{l}\text { Frequency of Ap* } \\
\text { peuranee on all } \\
\text { Five reating: }\end{array}$ \\
\hline Head & $\mathbf{1}$ & 0 & 19 \\
\hline Neck & 2 & 22 & 2 \\
\hline Byes & 4 & 1 & 22 \\
\hline Brom ox 1allow & 3 & 16 & 0 \\
\hline Bye detaxi, pup I1 & 6 & 26 & 0 \\
\hline Eye datall, propertien & 7 & 29 & $?$ \\
\hline Nose & 9 & 4 & 14 \\
\hline Roses tud dimenstan & 10 & 26 & 0 \\
\hline Brldge of noge. & 11 & 27 & 0 \\
\hline Nontrile & 12 & 27 & 0 \\
\hline Mouth & 13 & 3 & 19 \\
\hline Chin and torehesd & 17 & 7 & 0 \\
\hline Hatx I & 19 & 5 & 9 \\
\hline Halr II & 20 & 25 & 1 \\
\hline Arma & 24 & 4 & 7 \\
\hline Fingera & 28 & 13 & 1 \\
\hline Correct number of fingers & 29 & 23 & 0 \\
\hline Hands & 32 & 21 & 1 \\
\hline Lege & 33 & 3 & 19 \\
\hline Feet I & 35 & 8 & 12 \\
\hline Teat II, proportion & 36 & 26 & 1 \\
\hline Feet III, detall & 37 & 29 & 0 \\
\hline Placement of feet & 40 & 25 & 0 \\
\hline Attachment of arms and legs & 41 & 18 & 2 \\
\hline Clothing & 43 & 18 & 2 \\
\hline Sleeve I & 44 & 28 & 0 \\
\hline sleeve II & 45 & 29 & 0 \\
\hline Neckline I & 46 & 29 & 0 \\
\hline Nechline $\mathrm{XI}$, collar & 47 & 29 & 0 \\
\hline Hatet $I$ & 48 & 26 & 0 \\
\hline Stelrt twadeledw to & & & \\
\hline Indiente pleats & 50 & 29 & 0 \\
\hline Garb, feninine & 52 & 28 & 0 \\
\hline Gaxb, a delinite type & 54 & 29 & 0 \\
\hline Irenk & 53 & 7 & 9 \\
\hline Truak, proportion & 56 & 12 & 2 \\
\hline Head Trimk, proportion & 57 & 21 & 0 \\
\hline Head, proportion & 58 & 5 & 6 \\
\hline Limbs, proportion & 59 & 27 & 0 \\
\hline $\begin{array}{l}\text { Arwo in propertien to } \\
\text { trunk }\end{array}$ & 60 & 28 & 0 \\
\hline Motor cooxdination: & 63 & 28 & 0 \\
\hline
\end{tabular}




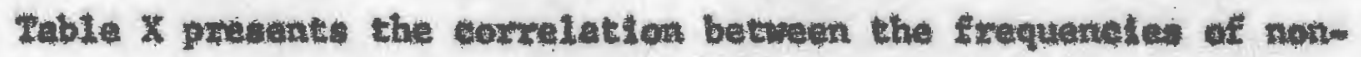

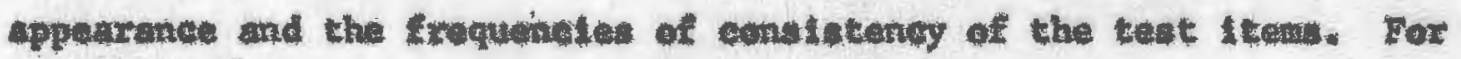

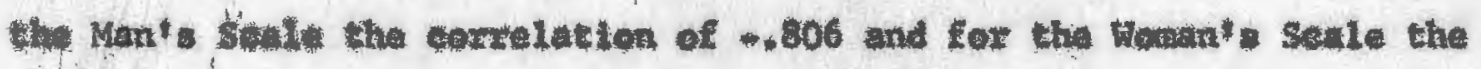

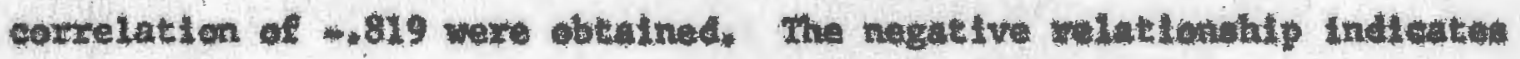

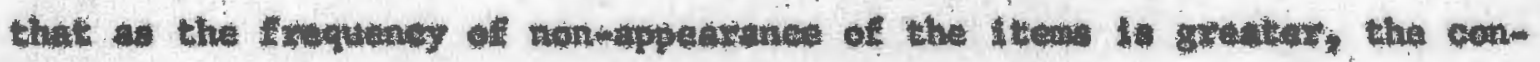
olutency of appearme the Item to less and viee verat.

\section{TaBus $\mathrm{X}$.}

CORRELATION BETHREN THE FREQURNCIES OF NON-APPRARANCE AND APFEARANCE OF TEST

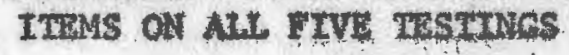

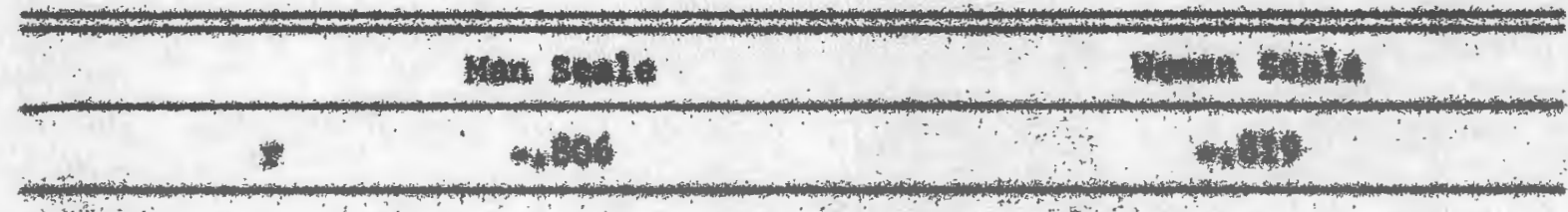

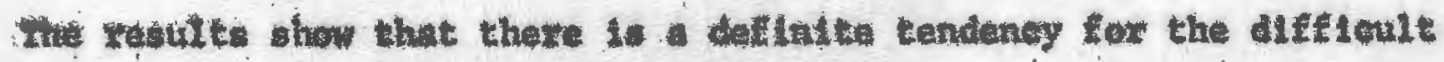

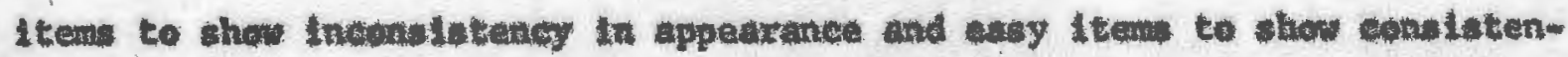

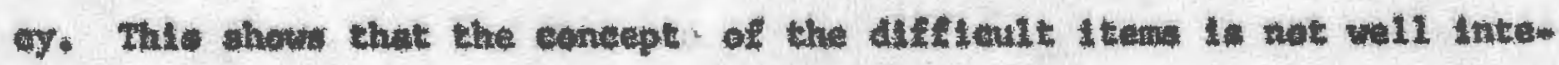

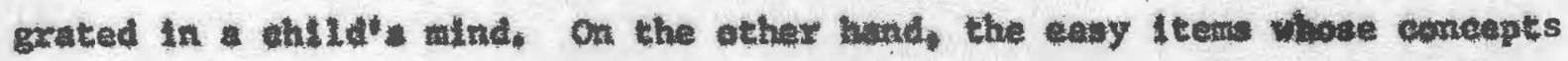

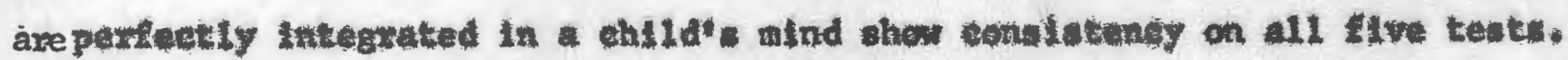


SURAARY AND CONCUSTOAS

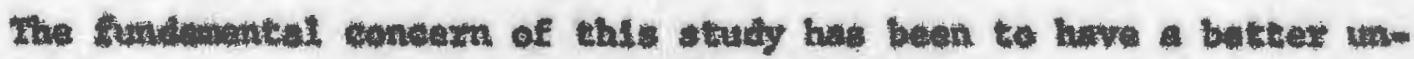

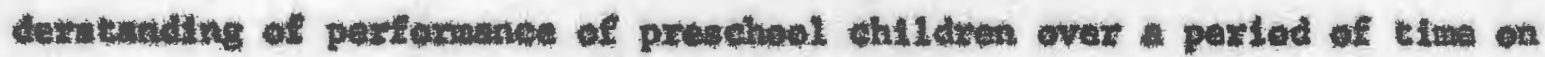

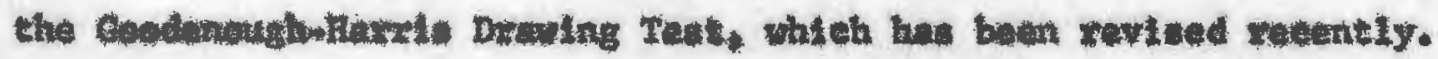

The subfect: of the wtudy were prochnol ehlldren enxolled at the

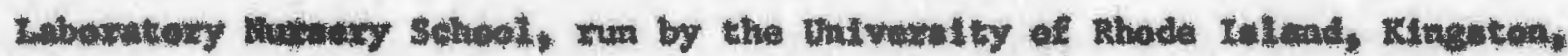

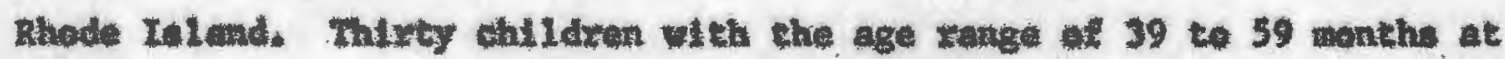

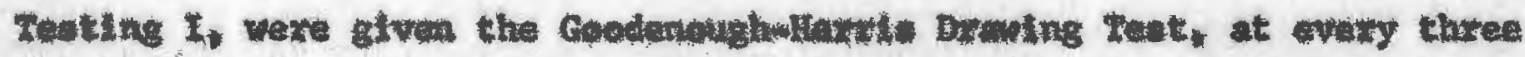

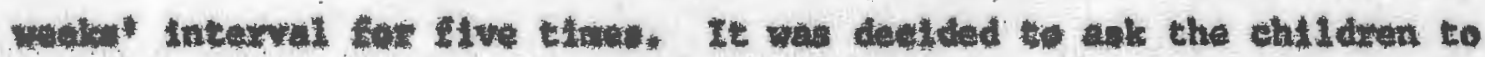

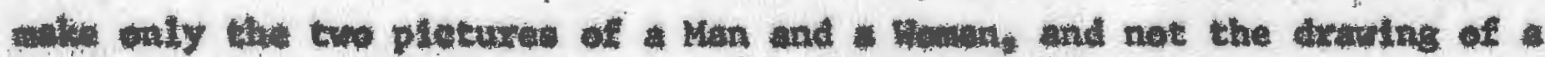

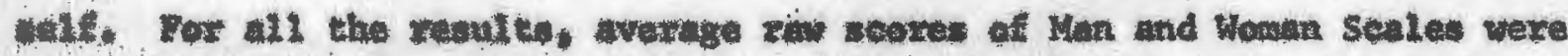
woed.

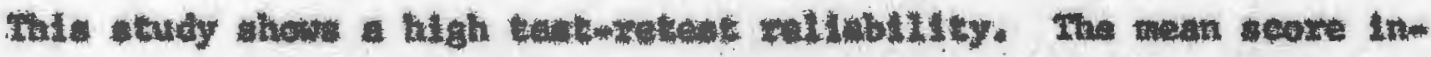

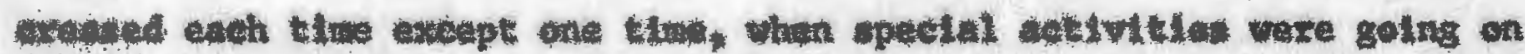

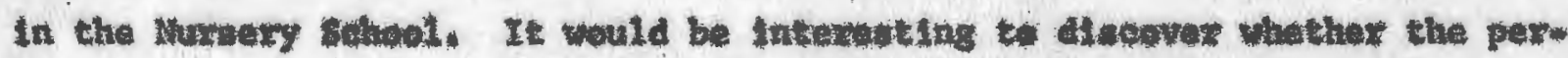

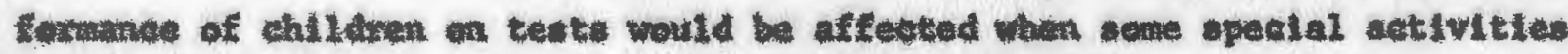
are andate on.

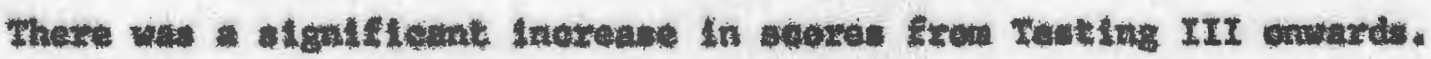

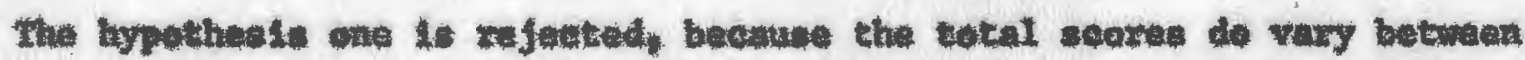

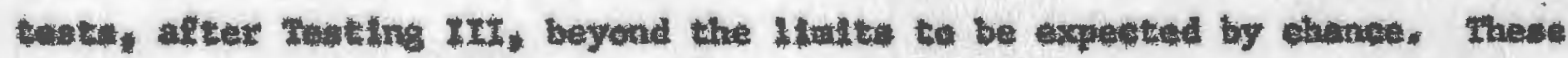
reaulte suggent the pulbitty of practice effeot after tonting III. It

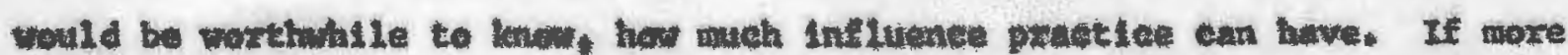

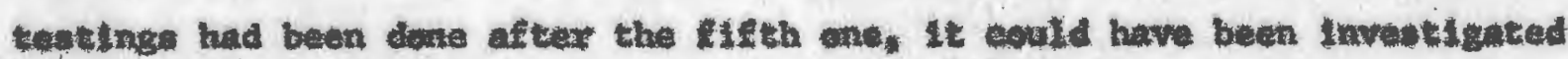
Whathes the proctice effect renche a nctain polat, bayotd which o child 
does not inerease in hil ceores.

On the zepeated teutingz, some ehlidren shosed stabillty 'on the

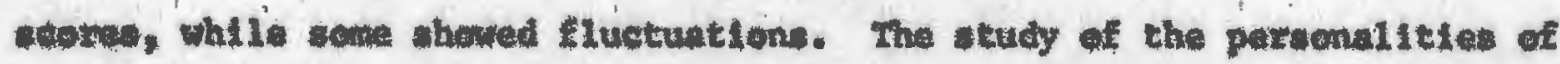

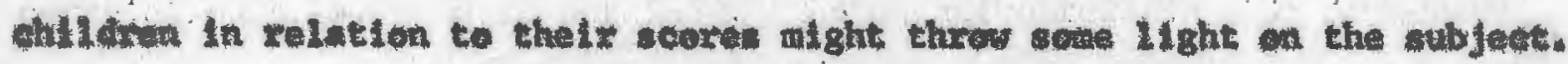

ca all ifve tectugn, high cartelatione were obtained betwewn the

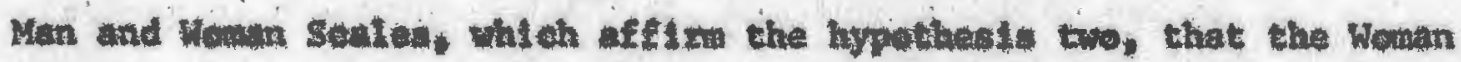

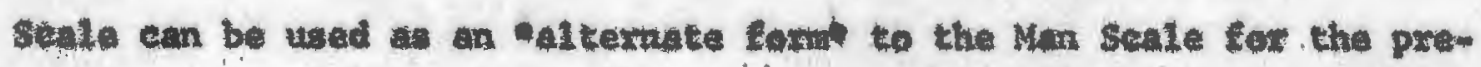
soheol ohlldren.

The average row scoses of the Draing Test corralated nubstaistinlly

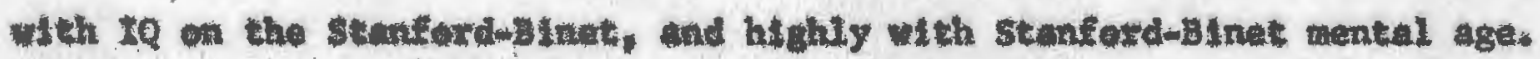

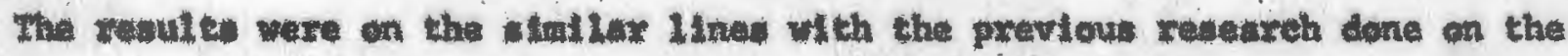

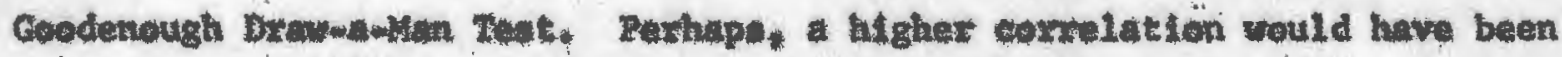

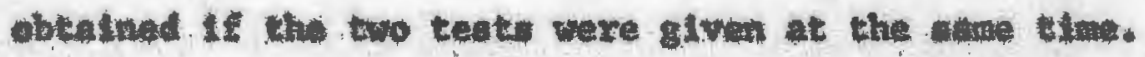

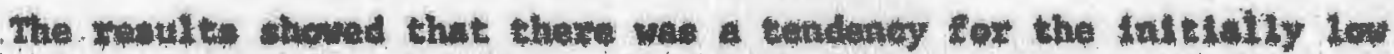

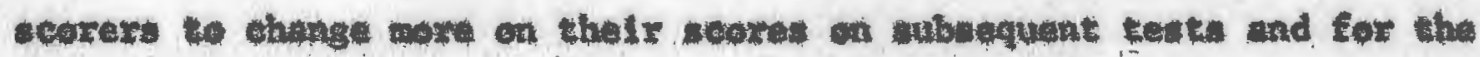

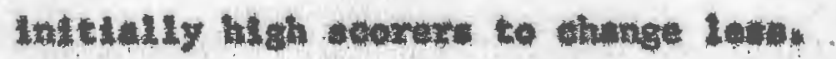

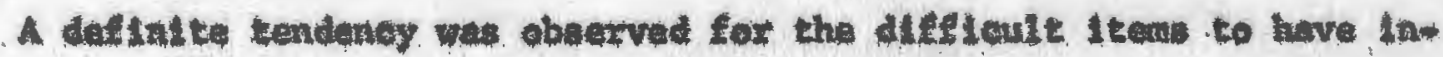
conplotent appearance and the easy itere to have consistent appeaxanes on all five testrge. These resulto affirm the hypothesto three, that aome

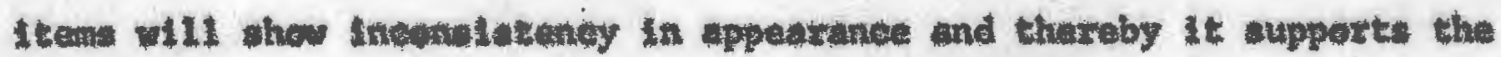

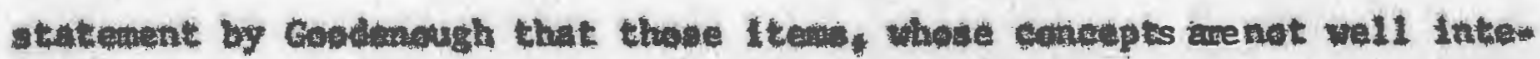

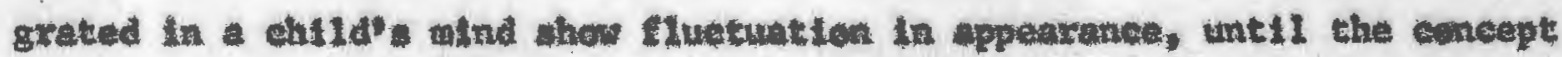
In well formed. S1mbe diffieult ttent axe those that are 11kely not to be

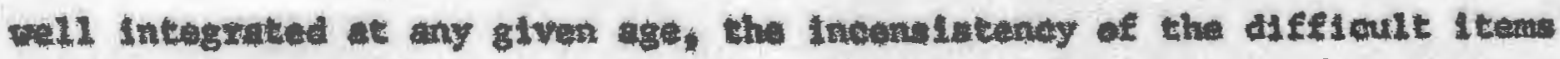

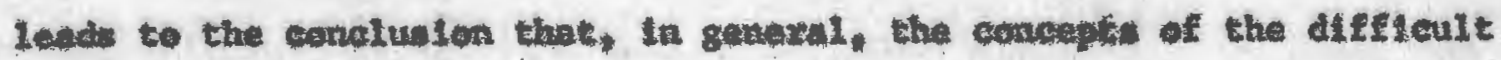
Itewe are not well integrated in a ohildts allu, 
BIBLIOCDAPHY 
BIBLLOCRAPUY

Books

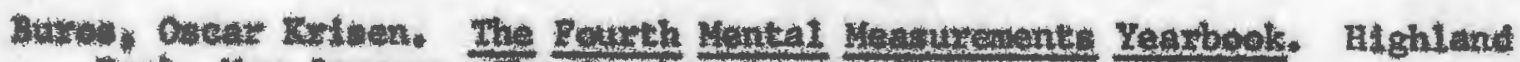

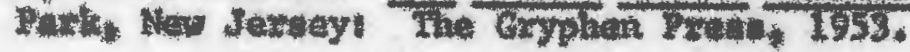

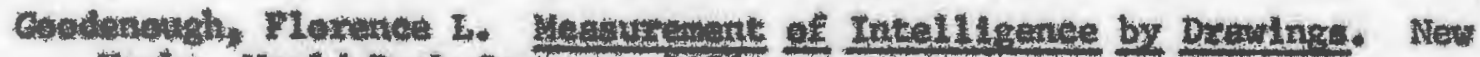
Yoxtsi World Bools Couplay. 1926,

Hurlt. Dale B. Children's Dreuings as Measures of Intellectual Maturtby. We Yatki Harcourt, Brace and horld, Imcorporation, 1963.

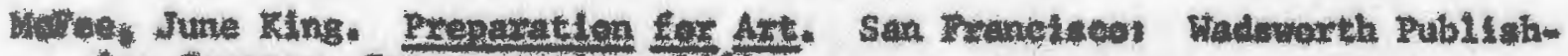
Ing Compan, Ineorpartetor, I961.

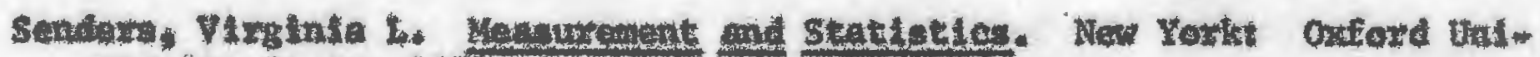
vextity Preste, 1958.

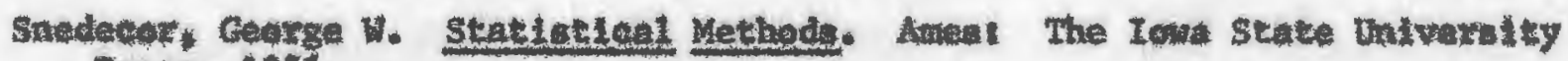
Pxest, 1958.

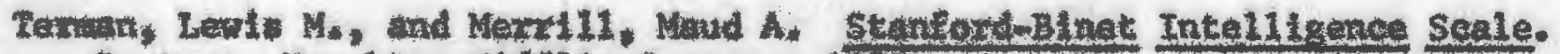
Hoston: Hetghten MiftLin Cexpituy, 1960.

\section{matrontcals}

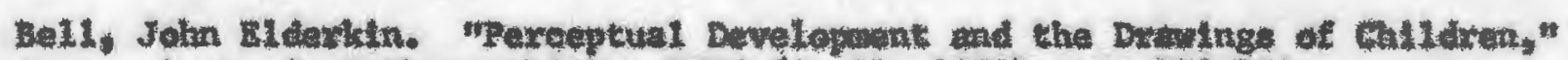

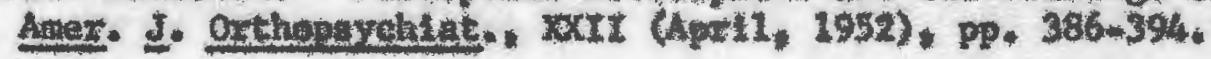

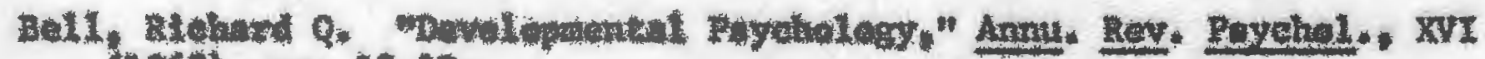
(1965),

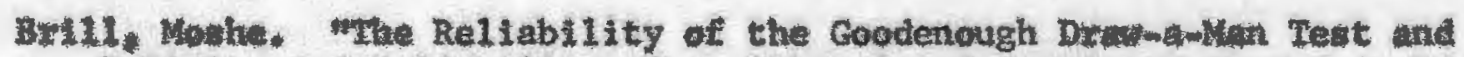
Valldtty and Rellabllity of an Abbreviated Scoring whot," I. Edue. Psychal., XXVI (Deceraber, 1933). pp. 701-708.

Estes, Betsy Wortk, at al Melationchtp betwen 1960 stanferd-Binet, 1937

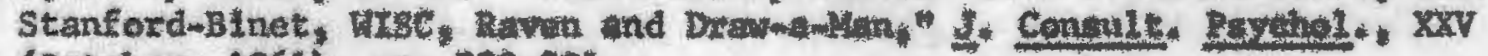
(October, 1961), pp, $388-394$.

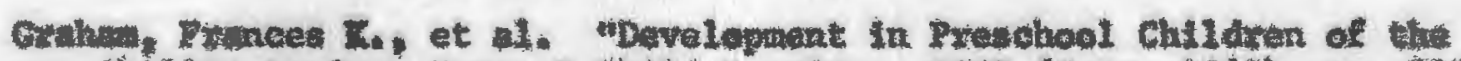

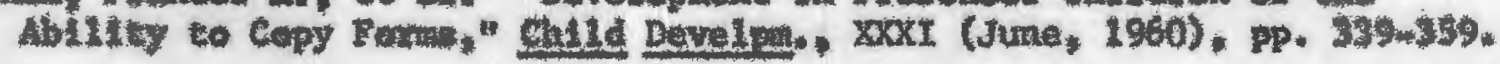

Harxis, Dale B. Mntra-Indtwidul vo. Intex-Indtvidual Condstency in

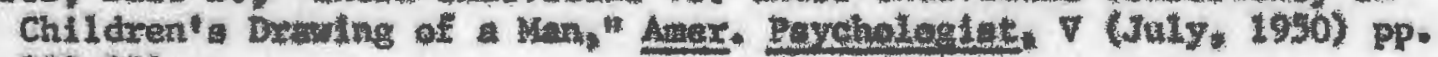
293-294. 
Rennedy, Wallace A. and Lindnex, Ronald S., "A Noxtateivi Study of the Coodenough Draum-Ben Test to Seuthezn Negzo Zlementary School Culltren." Ch11d Develpm. XXXV (Natch, 1964), pp. 32m62.

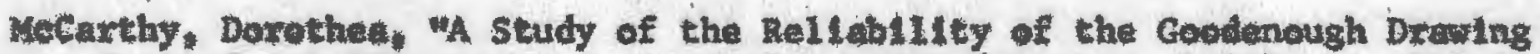
Test of Intelligence," J. Psychol. XIIII (Oetehex, 1944). Pp. 201-206.

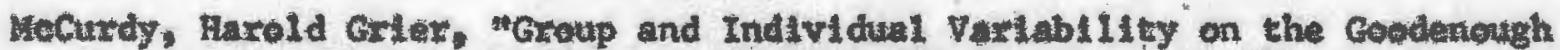

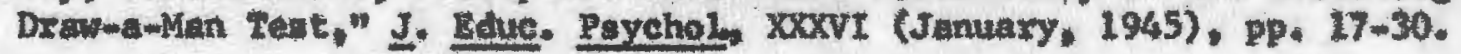

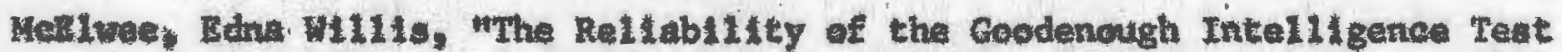

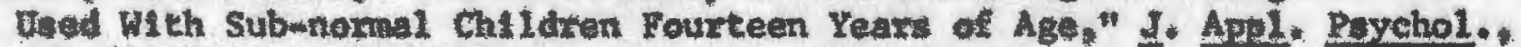
XVI (1932), PP. $217-218$.

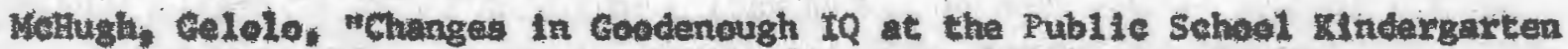

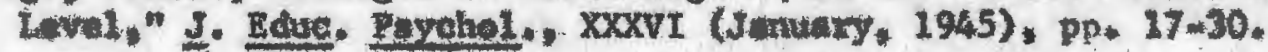

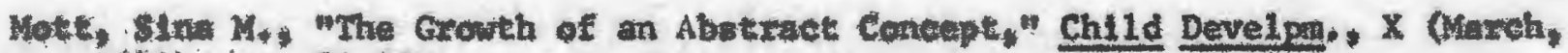
1949), $P$. 21-25.

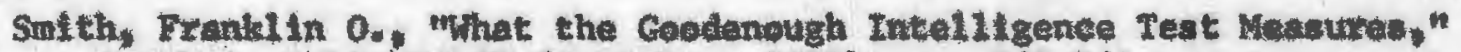

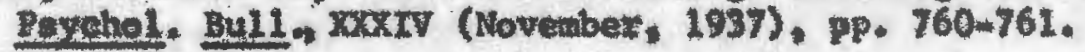

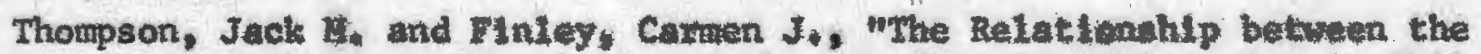

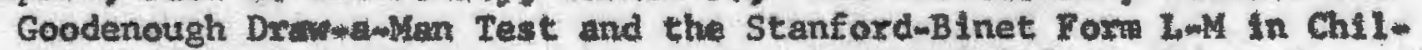
dren Referred for School Guldane Serviode" Cal1f. 3. Educ. Res. XIV (1963). pp. $19-22$.

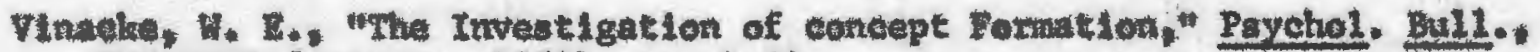

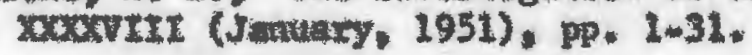

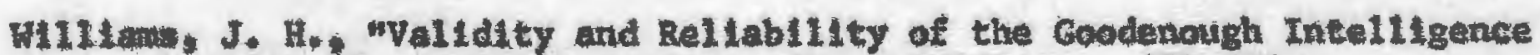
Tast," school and Sectety, Xxxx (Mmy, 1935). Pp. 653-656.

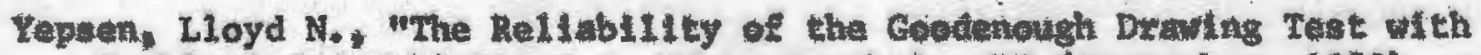

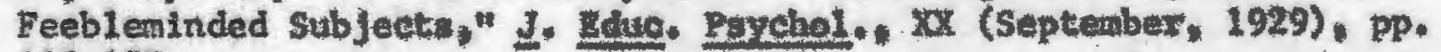
448.457. 
APPENDIX 


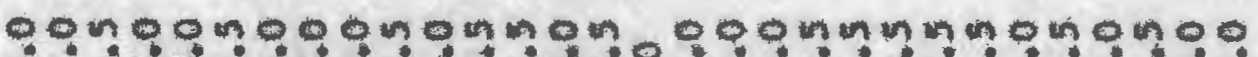

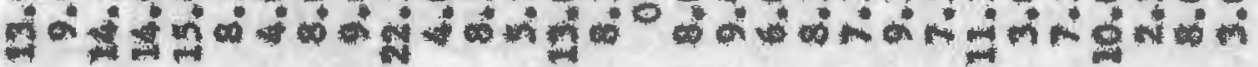

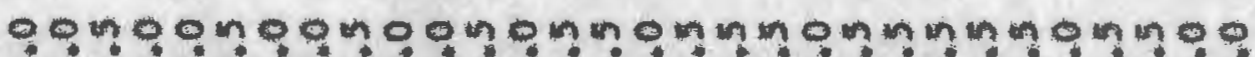

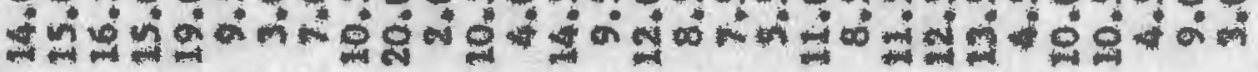

on moommommom

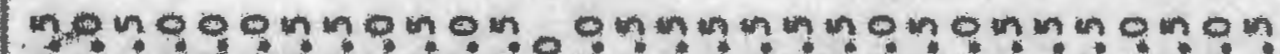

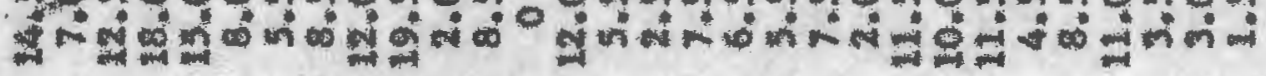

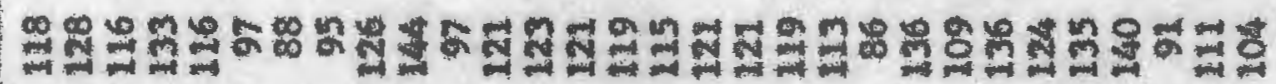

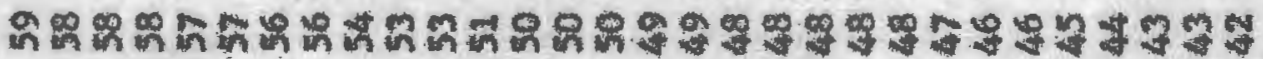

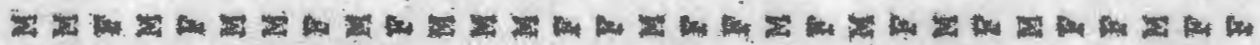




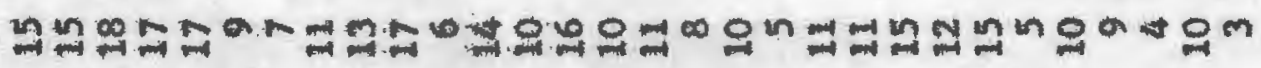

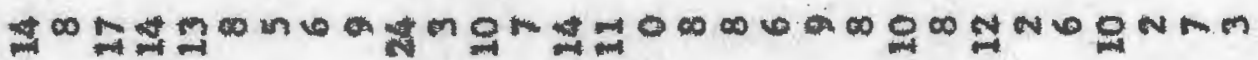

䭪

$\omega$

6

$\Leftrightarrow$

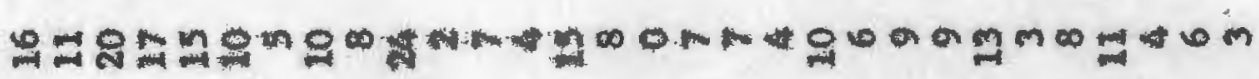

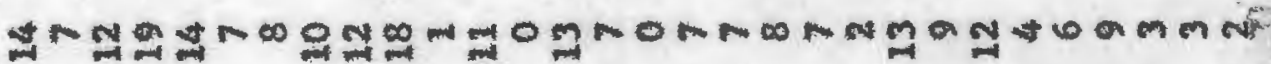
H

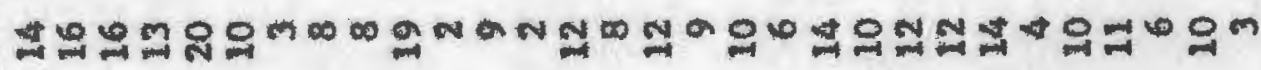
6

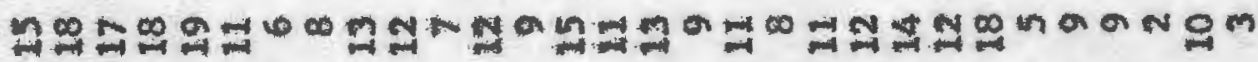

눌

然

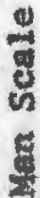

है

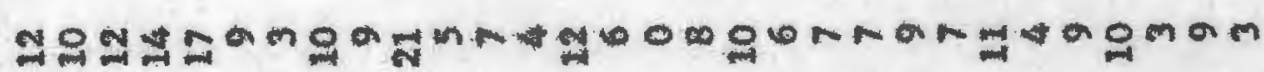

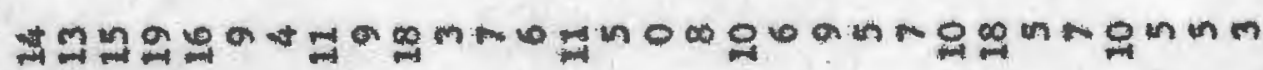
(1)

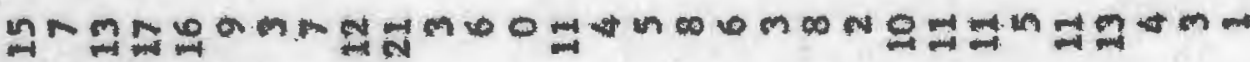

